\title{
Experimental and numerical analysis of the energy performance of a water/soil exchanger coupled to a cooling floor for North Africa
}

\author{
M.H. Benzaama ${ }^{a}$, S. Menhoudj ${ }^{b}$, C. Maalouf ${ }^{c}$, A. Mokhtari $^{\text {b }}$, M. Lachi ${ }^{\text {c }}$ \\ ${ }^{a}$ Ecole des Mines de Douai, IA, F-59500 Douai, France \\ ${ }^{\mathbf{b}}$ Université des Sciences et de la technologie d'Oran Mohamed Boudiaf, USTO_MB, BP 1505 El \\ M'Naouer,31000,Oran, Algérie \\ ${ }^{c}$ Université de Reims Champagne-Ardenne, laboratoire GRESPI/LTM (EA 4694), Reims, France
}

\footnotetext{
* Corresponding author (Mohammed-Hichem Benzaama Ph.D.).

$e$-mail address: mohammed-hichem.benzaama@imt-lille-douai.fr
}

\begin{abstract}
:
This paper presents an experimental and numerical study on the energy performance of a water / soil heat exchanger coupled to a cooling floor. The system shows two galvanized steel water tanks embedded at a shallow depth of $2 \mathrm{~m}$ from the ground and each with a volume of $2 \mathrm{~m}^{3}$. The experimental set up has enabled us to study these two cases: The first case considers the two tanks connected in parallel and coupled to the room, whereas the second case considers only one tank coupled to the cooling floor. An experimental device has been setup to measure the temperatures at different points as follow: indoor air temperature; surface temperature of the cooling floor; inlet and outlet tank temperatures. Experimental results were compared with those obtained from the simulation using Trnsys tools and a fair similarity was obtained. The numerical model made it possible to run a parametric study which revealed the most influential parameters on the energy efficiency of this system. A control strategy has been proposed to improve the energy efficiency of the water / soil heat exchanger. The control strategy used allows a lowering of the cooling floor surface temperature at the order of $2.5{ }^{\circ} \mathrm{C}$, the indoor air temperature at the order of $6{ }^{\circ} \mathrm{C}$ and the water outlet temperature of the tank at $2{ }^{\circ} \mathrm{C}$. The supply of night ventilation was introduced into the system with a regulation relative to the outside temperature. The control strategy of the underground tank systems and night ventilation gives an indoor air temperature reduction of $9{ }^{\circ} \mathrm{C}$ compared to the case without heat source, which gives a coverage rate of $65 \%$. Results obtained on the feasibility of this technique in the Mediterranean climate are promising.
\end{abstract}


Keywords: Energy performance, buried tanks, cooling floor, control strategy, night ventilation.

\section{Introduction}

The energy needs in the building are constantly growing to meet the requirements of occupants regarding the comfort of indoor environments. Cooling needs take a significant share in energy consumption due to electrical operation. The reduction in energy consumption and the ecological problems have highlighted the use of renewable energies, such as geothermal energy [1].

Geothermal heat is suitable for direct heat production or for heat storage. The volume and the cost of heat storage systems are among the most important issues that need to be addressed to enhance user acceptance [2]. However, one problem faced in operating geothermal heat is that collection or rejection heat from the ground alters the ground temperature, which can adversely affect the coefficient of performance (COP) [3].

The results obtained by Caliskan et al. [4] showed that the most sustainable system is the aquifer thermal energy storage, while the least sustainable system is the latent thermal energy storage. Moreover, Zhang et al. [5]reported that the sensible heat storage technologies considered using the underground thermal energy storage is more favorable than other technologies.

The water / soil exchanger is a geothermal system used to regulate indoor temperatures. The thermal behavior of the soil varies according to the depth, the thermo-physical properties of the soil and the climatic conditions. Jiang et al. [6] showed that the mass heat storage density and the effective mass heat storage density increased with increase inthe ambient temperature. On the other hand, Rohit Misra et al. [1] have shown that the transient thermal performance of the geothermal system is strongly dependent on the thermal conductivity of the soil and the duration of its continuous operation.

Shuhong Li et al. [7] presented a model that describes the real-time interaction between a ground source heat pump (GSHP) and the temperature variation of soil for long term periods. The results showed that the soil temperature increases from 2.56 to $3.00{ }^{\circ} \mathrm{C}$ after 15 years, and the cooling water inlet temperature is $36{ }^{\circ} \mathrm{C}$ after 9 years, which causes a decrease in the coefficient summer performance. Moreover, the average soil temperature at different depths decreased by $0.185^{\circ} \mathrm{C}$ in each year [8]. Furthermore, Muhammed Enes Kuyumcu et al. [9] 
indicated that 6-7 years' operational time span is needed to obtain the annual periodic operation condition.

Several investigations and case studies about thermal energy storage technology are available in the literature [10]. Rismanchi et al. [10] developed a model to determine the potential energy savings of implementing cold TES systems in Malaysia. They found that the overall energy usage of the cold storage strategy was almost $4 \%$ lower than the non-storage conventional system.

Moreover, Zhang et al. [11] analyzed the effect of various types of soil, the tank's volume and its wall thickness on the water temperature, by presenting a model of an underground water tank insulated with polystyrene. The tank is considered as a heat source in winter and a source of refreshment in summer. Yumrutas and Unsal [12] studied the effect of soil type on the water temperature of an underground tank coupled with a heat pump.

Ucar and Inalli [13] studied the transient temperature distribution of the soil surrounding a buried tank coupled to a solar collector using the Matlab code. Durao et al. [14] also proposed an algorithm to optimize the combined solar-underground tanks system by varying the volume of the underground tank and the surface of the solar collector to ensure the heating requirements of a greenhouse are met. For this purpose, Milewski et al. [15] presented an analytical model to study the parameters influencing the combined solargeothermal system as the volume of an underground tank and the surface of a solar panel under Polish climate. Yumrutas and Unsal [16] studied the energy performance of a heating system consisting of a heat pump and a buried tank coupled to a building. Their numerical results showed that a soil with low thermal conductivity gives a better annual performance for the system. They also showed that increasing the burial depth beyond 1 meter has only a slight effect on the system's performance.

Several researchers have shown interest in coupling the buried tank with solar thermal collectors under different climates [15-19]. Banjac et al. [19] presented a sizing methodology for sustainable heating-cooling system consisting of a heat pump coupled to thermal solar collectors and a buried water tank under Belgrade weather conditions. The results showed that the size of the tanks has a significant effect on the water temperature and that temperature amplitude decreases with tank volume increment. Besides, it can be seen that the tank burial depth has a minor effect on water temperature. 
From literature, only one work of M.H. Benzaama et al [20] is available on the buried tanks coupled directly to the cooling ground. In this study, the authors are interested in studying a combined system consisting of two buried tanks connected in series and an air / ground heat exchanger. The thermal behavior of the water in the tank has not been highlighted.

In continuation of this research work, a study on the thermal behavior of water in the tank for two different scenarios was proposed. In the first scenario, we considered two buried tanks not coupled to the cooling floor (The circulation pump turns OFF) to show the heat exchange between the ground and the water in the tank. In the second scenario, the buried tanks are considered to be coupled with the cooling floor (The circulation pump turns ON).

A parametric study was carried out to show the influence of tank volume, depth of burial and climate site on the water temperature in the tank. A regulatory strategy has been proposed to improve the energy efficiency of the system and the reduction in energy consumption. We introduced a night ventilation system to improve the indoor air temperature of the experimental cell.

The experimental study was conducted in two periods and on two different systems: during the month of July 2014, we studied the first case representing two buried tanks connected in parallel and coupled to the room. The second case was conducted during the month of July 2017 and it consists of a single buried tank coupled to the room.

\section{Mathematical formulation}

We proposed a buried tank filled with water at ground depth (fig.1). In order to describe the stratification, TRNSYS standard models used an N-node one-dimensional vertical discretization [21]. The plug-flow tank (Type 38) usually involves book-keeping methods to keep track of the size, temperature and position of the nodes as they move through the tank. In plug-flow models, the number of plugs (nodes) depend on the operating conditions (inlet mass flow rate) [22]. The overall conductance for heat loss from any segment, $(U A)_{i}$, depends on its surface area and a user-supplied overall loss conductance $U A$. The total loss from the tank is [23]:

$$
Q_{\text {loss }}=\sum_{i=1}^{N}(U A)_{i}\left(T_{i}-T_{\text {env }}\right)
$$

With $T_{e n v}$ is environmental temperature for losses and $T_{i}$ temperature of ith segment 
The energy input to the tank due to the inlet stream is:

$$
Q_{\text {in }}=\dot{m} C_{p}\left(T_{\text {inlet }}-T_{\text {outlet }}\right)
$$

With $\dot{m}$ being mass flow and $C_{p}$ is the specific heat of the water.

The transient temperature outside the buried tank is given by the following partial differential equation Recep Yumrutas et al [16]:

$$
\frac{\partial^{2} \mathrm{~T}}{\partial^{2} \mathrm{r}}+\left(\frac{2}{\mathrm{r}}\right) \frac{\partial \mathrm{T}}{\partial \mathrm{r}}=(1 / \alpha) \frac{\partial \mathrm{T}}{\partial \mathrm{t}}(3)
$$

The energy transferred to the tank is equal to the difference between the sensible energy and the heat losses of the tank towards the surrounding ground by conduction. It is expressed by the following equation [16]:

$$
\mathrm{Q}=\rho_{\mathrm{w}} \mathrm{V}_{\mathrm{w}} \mathrm{C}_{\mathrm{w}} \frac{\mathrm{dT}_{\mathrm{w}}}{\mathrm{dt}}-\mathrm{kA} \frac{\delta \mathrm{T}}{\delta \mathrm{r}}(\mathrm{R}, \mathrm{t})(4)
$$

With :

- $\rho_{\mathrm{w}}$ : density of the water.

- Vw: Volume of the water.

- $\mathrm{Cw}$ : Heat capacity of the water.

- $\quad \mathrm{k}$ : Thermal conductivity of the soil.

- $\quad$ R: Radius of the tank.

- A:Surface of the tank.

- $\quad \alpha$ : Thermal diffusivity of soil.

The variation in the internal energy $\Delta U$ of the water in the reservoir is defined by Banjac [19]:

$$
\Delta \mathrm{U}=\rho_{\mathrm{w}} \mathrm{V}_{\mathrm{w}} \mathrm{c}_{\mathrm{pw}} \Delta \theta_{\mathrm{w}}(5)
$$

- $\Delta \theta_{\mathrm{w}}$ : change in temperature of the water in the tank.

The total heat received by the water in the tank in 1 hour is defined by Banjac [19]:

$$
\mathrm{Q}_{\text {in, } 1 \mathrm{~h}}=\Delta \mathrm{U}+\mathrm{Q}_{\mathrm{out}, 1 \mathrm{~h}}(6)
$$


With $\mathrm{Q}_{\text {in, } 1 \mathrm{~h}}$ is the total heat received by the water in the tank in $1 \mathrm{~h}, \mathrm{Q}_{\text {out }, 1 \mathrm{~h}}, 1 \mathrm{~h}$ is the total heat supplied by the water in $1 \mathrm{~h}$.

The temperature of the water at the outlet of the tank is one of the factors influencing the temperature of the cooling. The quantity of heat recovered by the cold water passed into the cooling floor hydraulic circuit is expressed as follows [23]:

$$
\mathrm{q}_{\mathrm{p}}=\mathrm{C}_{\mathrm{w}} \mathrm{G}_{\mathrm{w}} \varepsilon_{\mathrm{px}}\left(\mathrm{T}_{\mathrm{wi}}-\mathrm{T}_{\mathrm{px}}\right)(7)
$$

Où $\mathrm{C}_{\mathrm{w}}$ et $\mathrm{G}_{\mathrm{w}}$ are the specific heat and the mass flow of water respectively, $\varepsilon_{\mathrm{px}}$ is the overall coefficient of heat transfer. Twiis the water temperature at the inlet of the hydraulic circuit,Tpxis the average temperature of the hydraulic circuit's surface.

\section{Presentation of the case study}

\subsection{Location of the experimental cell}

The experimental cell is located at the Institute of Civil Engineering IGCMO of the University of Science and Technology, Mohamed Boudiaf, in the municipality of Es-Senia, Oran city (Algeria). The site is located at $35.65^{\circ}$ North latitude, $0.62^{\circ}$ West longitude at about 105 meters altitude above sea level.

\subsection{Description of the studied geothermal system}

The experimental cell occupies an area of approximately $40 \mathrm{~m}^{2}$, which is oriented East-West with windows on the south facade and consists of two identical rooms: the room $\mathrm{A}$ is equipped with a hydraulic circuit (reversible floor, heating / cooling) and the room B is used as a technical room (witness) housing all the equipment needed for the measurement system. The internal dimension of each room is $4.7 \mathrm{~m}$ in length, $3.7 \mathrm{~m}$ in width and $2.8 \mathrm{~m}$ in height (fig.2).

The experimental cell was made in the form of an insulated construction. The composition of the vertical walls, the high floor and the low floor are shown in tables 1, 2 and 3.

The hydraulic circuit of room A is coupled to a geothermal system consisting of two circular galvanized steel sheet tanks, buried in the ground at a shallow depth of $2 \mathrm{~m}$ and connected in 
parallel(fig.3). Each tank has a length of $2 \mathrm{~m}$, a diameter of $1.2 \mathrm{~m}$ and a thickness of $2 \mathrm{~mm}$ with a total volume of $2 \mathrm{~m}^{3}$ which is provided with a gauge for monitoring the water level. A set of valves installed in two manholes allows the connection of the two tanks: in parallel, in series or the operation of the system with a single tank (fig.4).

The physical properties of the soil are shown in Table 4:

Thermocouples connected to an acquisition chain of type (KEITHLEY 7700) made it possible to record the temperatures at various sensitive points of the system with a time frame of 1 hour

The temperatures recorded are as follow:

- The inlet and outlet temperature of the water tank;

- The surface temperature of the cooling floor;

- The temperature of the air inside the room A.

A mini OREGON weather station (precision $+/-0.5^{\circ} \mathrm{C}$ ) was installed and connected to a computer, which allow the recording of weather data of outside temperature as well as indoor and outdoor humidity.

\section{Experimental results}

\subsection{Case of two buried tanks coupled to the cooling floor}

During the month of July 2014, we studied the first case representing two tanks connected in parallel coupled to the room. Three thermocouples are placed in room A at different positions and at a height of $70 \mathrm{~cm}$ in order to measure the distribution of indoor air temperature. We followed the evolution of the following temperatures for a period of 15 days in July:

- The outside air temperature as well as the indoor and outdoor humidity of room A.

- The temperatures at the entrance and at the surface of the floor.

- The temperature of the indoor air. 
Figure 5 shows the evolution of indoor and outdoor relative humidity during the measurement period. The indoor humidity values vary between 40 and $60 \%$ which corresponds to the criteria of thermal comfort (NF S90-351 standard), while the external relative humidity varies between 20 to $85 \%$. The temperature of the outside air varies between 17.5 and $39^{\circ} \mathrm{C}$.

The thermal comfort for the cooling period is very complex due to interaction between several environmental variables, such as the indoor operative temperature which should not exceed $26^{\circ} \mathrm{C}$ and the surface temperature of the cooling floor which must be between 19 and $27^{\circ} \mathrm{C}$ [26]. In addition, there is a risk of condensation when the surface temperature of the floor becomes lower than the indoor dew point temperature.

Figure 6 shows the temperature readings at the entrance and at the floor center surface. Both temperatures have the same profile. The temperature at the entrance of the cooling floor varies between 22 and $25^{\circ} \mathrm{C}$ and the temperature on its surface takes an ascending shape, starting at $23{ }^{\circ} \mathrm{C}$ and reaching a maximum of $26.5{ }^{\circ} \mathrm{C}$. The difference between the two temperatures reaches $1.5^{\circ} \mathrm{C}$. The results obtained during the experimental period comply with the thermal comfort criteria. Figure 7 shows the comparison between dew point temperatures calculated using an approach presented in [27] and the surface temperature. Results show that the dew point temperature is below the temperature of the cooling floor, which confirms that the effect of the condensation of the cooling floor is neglected.

The evolution of the indoor air temperature in the experimental cell is shown in Figure 8. It varies between 23 and $26.8^{\circ} \mathrm{C}$ for an outside air temperature ranging between 17.5 and 36 ${ }^{\circ} \mathrm{C}$, where it is clear that the indoor air temperature is in a comfortable range [26].

\subsection{Case of a buried water tank coupled to the cooling floor}

Water temperature at tank inlet and exit as well as the surface temperature of the cooling floor and the indoor air temperature were monitored for 15 days in July 2017 for the floor coupled only to one tank. The diagram of the temperature recording device is shown in figure 9. The system operates at full load (pump operation $24 \mathrm{~h} / 24 \mathrm{~h}$ ).

Figure 10 shows the evolution of the water temperature at the entrance and exit of the tank. At the exit, temperature is less than the entrance and it varies between $23.5{ }^{\circ} \mathrm{C}$ and $27.8{ }^{\circ} \mathrm{C}$, while at the inlet, it varies between $26.6^{\circ} \mathrm{C}$ and $30.7^{\circ} \mathrm{C}$. 
For the same case, figure 11 shows the indoor air temperature and it varies between $25.5{ }^{\circ} \mathrm{C}$ and $30^{\circ} \mathrm{C}$, while the outdoor temperature air varies between $14.1^{\circ} \mathrm{C}$ and $32.6^{\circ} \mathrm{C}$. The indoor air temperature exceeds the thermal comfort threshold [26]. A single buried tank does not maintain the indoor air in a comfort zone.

\section{Simulation under Trnsys and validation}

\subsection{Validation of the model of two water-tanks}

The simulations of the studied system are made using TRNSYS software which is designed to simulate the energy performances of dynamic systems (fig.12). The essential types used for the simulation are:

\section{- " Type 38 " to the model of the two buried tanks connected in parallel:}

Type 38 (Plug-Flow Tank) models a stratified storage tank. It uses variable segments of fluid, which allows the model to simulate a particular zone of the tank using small segments without requiring a large total number of nodes or small time steps [28]. The essential parameters used in the simulation include:

1. The total volume of the tank: 2000 liters.

2. The thermal conductivity of the tank (galvanized sheet): $48 \mathrm{~W} / \mathrm{m} . \mathrm{K}$.

3. The thermal conductivity of the water: $0.6 \mathrm{~W} / \mathrm{m}$. K.

4. Initial water temperature in the tank: $20^{\circ} \mathrm{C}$.

- " Type 56" describes the dynamic thermal behavior of a multi-zone building :

The Type 56 Multi-zone Building model provides a more efficient way of calculating the interaction between 2 or more zones by solving the coupled differential equations while utilizing the matrix inversion techniques [28].The essential parameters used in the simulation include:

1. Heat convection coefficient of the cooling floor: $0.2 \mathrm{~W} / \mathrm{m}^{2} \cdot \mathrm{K}$. [29]

2. The thermal conductivity and the heat capacity of building materials of the cell

- "Type $711 "$ is used to model the thermal exchange between the tank and the ground:

This component can be used in conjunction with most pipe models to calculate the energy exchange through the sides of a horizontally oriented pipe that is entirely buried beneath the ground surface. As inputs, the model takes the $U$ values of the pipe as well as the temperature 
of each axial pipe node [28]. In return, Type 701 computes the temperature of each pipe node I soil node boundary, passing those temperatures back to the pipe model for its own loss calculations [28]. The essential parameters used in the simulation include:

1. The burial depth of the tank: $2 \mathrm{~m}$.

2. The thermal conductivity of the soil: $1.5 \mathrm{~W} / \mathrm{m}$. K.

3. The heat capacity of the soil: $920 \mathrm{~J} / \mathrm{kg} . \mathrm{K}$.

4. Average surface temperature: $20^{\circ} \mathrm{C}$.

5. Thickness of radial node: $0.1 \mathrm{~m}$

The numerical model of the two buried tanks coupled with the experimental cell was validated using the experimental data for an 11-day period in July 2014. Two years of initialization have been considered in order to ensure thermal stabilization of the buried tank.

Figure 13 shows the evolution of the numerical and experimental results for the indoor air temperature. A good agreement was obtained between experience and simulation. The recorded temperature of the indoor air varies between 23 and $26.8{ }^{\circ} \mathrm{C}$, while the numerical one varies between 23.5 and $27.6^{\circ} \mathrm{C}$.

The surface temperature of the cooling floor was also validated (Figure 14). From the results, it was noted that the two curves (experimental and numerical) have the same tendencies. The recorded temperature of the surface of the refreshing floor varies between 23 and $26.5{ }^{\circ} \mathrm{C}$, while the numerical one varies between 22.5 and $25.5^{\circ} \mathrm{C}$.

\subsection{Validation of the model for the single water tank case}

The numerical model of a single buried tank coupled to the experimental cell was validated by experimental results of a 15-day period in July 2017. Figure 15 shows that both temperature curves at the tank entrance (simulation and experimental) are in good agreement with a maximum deviation of $1{ }^{\circ} \mathrm{C}$. The measured temperature of the fluid at the inlet of the tank takes a value of $27{ }^{\circ} \mathrm{C}$ at the beginning of the measurement period, which gradually increases to reach a minimum temperature of $30{ }^{\circ} \mathrm{C}$. The one obtained by simulation varies between 26 and $30{ }^{\circ} \mathrm{C}$. 
The indoor air temperature for this period was also validated as shown in Figure 16. Based on the results, it was observed that the two indoor air temperature curves (simulation and experimental) follow the same trends. The recorded temperature of the indoor air varies between 25.5 and $30{ }^{\circ} \mathrm{C}$, and those obtained by simulation varies between 26 and $29^{\circ} \mathrm{C}$.

\section{Optimization}

We present in this section a control strategy for the water / soil heat exchanger to optimize the energy efficiency of this system. For this purpose, we show firstly the thermal behavior of the underground tank in free evolution (pump OFF) to evaluate the heat transfer between soil and water for different burial depths. Secondly, we present the system operation for several scenarios to highlight a process of control system in order to reduce the cooling requirements.

\subsection{Simulation of the water temperature in the tank in free evolution}

The simulation was made considering the fact that the tank is not coupled to the cooling floor and the accelerator pump is off. We are interested in studying the thermal behavior of the tank and the ground-tank interface in free evolution in order to define the thermal transfer between soil and water in the buried tank. The main objective of this step is to understand the thermal behavior of a buried tank for one year before application. Figure 17 shows that the thermal behavior of water varies between the two seasons, summer and winter. For the summer period, the results show that the water temperature in the tank for full August is cooler than that of the outside air with a difference of $17{ }^{\circ} \mathrm{C}$. The initial conditions of one year were considered in the simulations for the thermal stability of the system. At a depth of $2 \mathrm{~m}$, the soil temperature varies between $16.5^{\circ} \mathrm{C}$ and $23.4{ }^{\circ} \mathrm{C}$, the average temperature of the water in the tank varies between $18{ }^{\circ} \mathrm{C}$ and $22{ }^{\circ} \mathrm{C}$ for an outside air temperature, ranging from $3{ }^{\circ} \mathrm{C}$ to $37.5{ }^{\circ} \mathrm{C}$ (Fig.17). The results obtained confirm the geothermal potential for cooling and the interest of storing cold heat in underground tanks.

The thermal behavior of the water in the tank is influenced by several factors, such as depth. As a result, we have varied the burial depth of the tank for depths $(Z=1.50 \mathrm{~m}, \mathrm{Z}=2 \mathrm{~m}$ and $\mathrm{Z}$ $=3 \mathrm{~m}$ ). The simulation is done in free evolution (circulation pump stopped). This step shows the thermal behavior of the water before the system is switched on for different depths, which allow the designer to choose the optimal depth for the best system operation. Figure 18 shows 
that the average temperature of the water in the tank and the temperature, soil-tank interface vary according to the depth. From a depth $Z=5 \mathrm{~m}$, the amplitude of the temperature of the water in the tank and that of the ground tank interface decreases. For $Z=10 \mathrm{~m}$, the difference between the average temperature of the water and the temperature of the ground-tank interface is negligible, the average water temperature stabilizes almost with the temperature of the surrounding soil (Fig. 19).

This section has made it possible to understand the thermal behavior of the water / soil exchanger and the interrelationship between water and soil for several depths in free evolution. The following section presents the coupling of the water / soil heat exchanger with the cooling floor for several case studies.

\subsection{Simulation of the water temperature: System start-up.}

This section describes the thermal behavior of the water in the tank in the case of system start-up. The thermal behavior of the buried tank is influenced not only by the depth but by storage volume, climatic conditions and the type of soil.

Figure 20 shows a parametric study on the effect of volume on the water temperature in the tank. The simulations are run for a tank volume of 2, 4 and $10 \mathrm{~m}^{3}$ (fig.23). We note that the change in volume affects the average temperature of the fluid in the buried tank. The increase in tank volume increases the exchange surface.

The temperature of the soil is influenced by the outside temperature and the solar radiation incident on the ground. Based on this, the geothermal system has been tested for three cities: Oran is a coastal city with a mid-dry Mediterranean climate and clay soil. Bechar is an internal city located in the North West Sahara with an arid climate and sandy soil. Adrar is located in the south-West under hyper-arid Saharan climate with sandy soil as shown in figure 21. The climatic conditions of the three cities are shown in table 5 [25].

The simulations are run for both cases: a single tank $\left(2 \mathrm{~m}^{3}\right)$ and two tanks $\left(4 \mathrm{~m}^{3}\right)$ (at $2 \mathrm{~m}$ depth). Average tank temperature is shown in figure 22.The results show that both volumes are insufficient to provide cooling for both climates of Adrar and Bechar. In order to improve the energetic efficiency of the system, the following section presents a control strategy for the 
good functioning of the system in order to optimally exploit this geothermal potential. The control strategy has been tested only for the climate of Oran city.

\subsection{Control strategy}

The first step in this approach is to present the contribution of the regulation on the temperature of the water in the tank. For this case, we introduced a control system which allows operating the circulation pump at intermittent periods:

- Activate the circulation pump from 8 am until 7pm.

- Deactivate the circulation pump in the evening between $7 \mathrm{pm}$ and $8 \mathrm{am}$ to allow the recharging of the tank at the night.

When the system is not regulated (pump operation $24 \mathrm{~h} / 24 \mathrm{~h}$ ), the temperature of the water leaving the tank in July varies between $26.5{ }^{\circ} \mathrm{C}$ and $30{ }^{\circ} \mathrm{C}$ (fig. 23). When introducing the control (intermittent pump operation), the water temperature decreases and varies between $25.6{ }^{\circ} \mathrm{C}$ and $28.5^{\circ} \mathrm{C}$. This temperature difference reaches $2{ }^{\circ} \mathrm{C}$. The control system makes it possible to lower the temperature of the water leaving the tank. This shows that stopping the pump between $7 \mathrm{pmin}$ the evening and 8am in the morning allows for a better heat exchange between the water at rest in the tank and the ground which increases the storage of thermal energy (fig. 23).

This reduction in the water temperature of the tank has a direct influence on the temperature of the cooling floor (fig.24). The results in figure 24 show that when the system is regulated, the floor surface temperature varies between $22{ }^{\circ} \mathrm{C}$ and $28.4{ }^{\circ} \mathrm{C}$ which gave a reduction of 2.5 ${ }^{\circ} \mathrm{C}$ compared to the case without regulation. The temperature gain provided by the control strategy at the cooling floor level, improved the indoor environment. Using the control strategy, the indoor air temperature of the room decreases by an average of $6{ }^{\circ} \mathrm{C}$ compared to that of the room in free evolution (without coupling with the buried tank). When the system operates without cutting the control pump, the indoor air temperature decreases by an average of $4{ }^{\circ} \mathrm{C}$ (fig.25).

\subsection{Effect of night ventilation on the indoor air temperature of the room}

The use of night ventilation has been investigated by several researchers such as M.C. Lekhal et al [31]. In this paper, the thermal performance of a residential house equipped with earth- 
air heat exchanger and night ventilation was investigated to improve the cooling conditions during summer. The authors show in this study the usefulness of night ventilation for the improvement of the indoor environment for the case of an experimental cell coupled to earthair heat exchanger. For this purpose, we propose in this section the simulation of the indoor air temperature during the month of July by considering different scenarios:

- Room free evolution (without source)

- The tank is coupled to the room; the circulation pump runs $24 \mathrm{~h} / 24 \mathrm{~h}$ (without regulation).

- The tank is coupled to the room; the circulation pump runs during the day from 8am to $7 \mathrm{pm}$ (With regulation).

- Between 7pm and 8 am, the pump is stopped. During this period, the outside air temperature decreases and room night ventilation is used to refresh the indoor air with a flow rate of $90 \mathrm{~m}^{3} / \mathrm{h}$. The operation of the night ventilation is controlled depending on the outdoor temperature and it is stopped when the outdoor temperature is higher than the indoor temperature.

Figure 26 shows the indoor air temperature for the cited scenarios. It was observed that combining tank operation during the day with night ventilation results ina lower indoor air temperature than the case using the tank day operation only. This reduction can reach $3{ }^{\circ} \mathrm{C}$. The average temperature of the indoor air in the case of a combined system (buried tank overnight ventilation) is equal to $26{ }^{\circ} \mathrm{C}$ (Fig.25).

Finally, Table 6 presents a summary table of the gain provided by the optimization strategy presented in section 6 . The results found show that the control strategy reduces the water temperature in the tank by $2{ }^{\circ} \mathrm{C}$. However, the buried tank with regulation reduces the indoor air temperature by $6{ }^{\circ} \mathrm{C}$ with a coverage rate of $45.43 \%$. The coverage rate provided by the buried tank without regulation is $40.13 \%$.

The regulation strategy brings a gain in indoor air and cooling floor surface temperatures of 2 ${ }^{\circ} \mathrm{C}$ and $2.5^{\circ} \mathrm{C}$ respectively, compared to the case without regulation.

The results show that the night ventilation and the regulated buried tank provide a temperature gain of $9{ }^{\circ} \mathrm{C}$ compared to the case of an experimental cell without heat source, which gives a coverage rate of $65 \%$. 


\section{Conclusion}

This study investigated the feasibility and the effects of coupling a cooling floor to buried water tanks for Algerian climates and more particularly for Oran City.

Results obtained showed that the use of this technique is promising for Mediterranean climates, but limited for hotter weathers. The risk of condensation on the surface of the floor is was too low during the experimental monitoring.

Results showed that for a period of one year, at a depth of $2 \mathrm{~m}$, the average temperature of the water in the tank in free evolution varies between $18{ }^{\circ} \mathrm{C}$ and $22{ }^{\circ} \mathrm{C}$. This temperature varies depending on the depth, the volume of the buried tank and weather condition.

An optimization study was done in order to improve the system cooling performance and it was shown that regulating the pump operation significantly reduces the cooling floor surface temperature by allowing the tank to recharge at night. This regulation makes it possible to reduce the surface temperature of the cooling floor and the water in the tank by $2.5{ }^{\circ} \mathrm{C}$ and 2 ${ }^{\circ} \mathrm{C}$, respectively.

When the system is regulated, the indoor air temperature decreases by an average of $6{ }^{\circ} \mathrm{C}$ compared to the case without a heat source. Combining this strategy with a night ventilation results in improving indoor conditions as indoor temperature decreases by $3^{\circ} \mathrm{C}$ compared to the case without night ventilation, which gives an indoor air temperature reduction of $9{ }^{\circ} \mathrm{C}$ compared to the case without heat source. The combination between the buried tank with regulation and a night ventilation ensures a coverage rate of $65 \%$, which reduces the cooling need for the Mediterranean climate.

Based on results found in this study, we recommended the use of buried tanks coupled with cooling floor in the Mediterranean climate, by taking into consideration the pump control strategy presented in section 6 and free cooling at night.

\section{References}

[1] Rohit Misra, Vikas Bansal, Ghanshyam Das Agrawal, Jyotirmay Mathur, Tarun K. Aseri, CFD analysis based parametric study of de rating factor for Earth Air Tunnel Heat Exchanger, Applied Energy 103 (2013), 266-277.

[2] Damien Gondre, Kévyn Johannes FrédéricKuznik, Specification requirements for interseasonal heat storage systems in a low energy residential house. Energy Conversion and Management 77 (2014) 628-636 
[3] Hua Qian a,b, Yungang Wang b,* Modeling the interactions between the performance of ground source heat pumps and soil temperature variations. Energy for Sustainable Development 23 (2014) 115-121

[4] Caliskan H, Dincer I, Hepbasli A. Thermodynamic analyses and assessments of various thermal energy storage systems for buildings. Energy Convers Manage 2012;62:109-22. http://dx.doi.org/10.1016/j.enconman.2012.03.024.

[5] Liang Zhang, Peng Xu, Jiachen Mao, Xu Tang, Zhengwei Li, Jianguo Shi, A low cost seasonal solar soil heat storage system for greenhouse heating: Design and pilot study, Applied Energy 156 (2015), 213-222.

[6] L. Jiang, R.Z. Wanga, L.W. Wanga, A.P. RoskillybInvestigation on an innovative resorption system for seasonal thermal energy storage. Energy Conversion and Management 149 (2017) 129-139

[7] Shuhong Li, Kefeng Dong, Jinyong Wang, Xiaosong Zhang, Long term coupled simulation for ground source heat pump and underground heat exchangers. Energy and Buildings 106 (2015) 13-22.

[8] Neng Zhu, Jingmei Wang介, Long Liu, Performance evaluation before and after solar seasonal storage coupled with ground source heat pump. Energy Conversion and Management 103 (2015) 924-933

[9] Muhammed EnesKuyumcu, HakanTutumlu, RecepYumrutas? Performance of a swimming pool heating system by utilizing waste energy rejected from an ice rink with an energy storage tank. Energy Conversion and Management 121 (2016) 349-357

[10] Rismanchi B, Saidur R, Masjuki HH, Mahlia TMI. Modeling and simulation to determine the potential energy savings by implementing cold thermal energy storage system in office buildings. Energy Convers Manage 2013;75:152-61. http://dx.doi.org/10.1016/j.enconman.2013.06.018

[11] Zhang, H F., Ge, X S and Ye, H., «Modeling of a space heating and cooling system with seasonal energy storage», Energy, Vol 32, 2007, P 51-58.

[12]Yumrutas, R., Kunduz, M., Ayhan, T., 2003. Investigation of thermal performance of a ground coupled heat pump system with a cylindrical energy storage tank. International Journal of Energy Research 27, 1051-1066. 
[13] Ucar, A., Inalli, M., 2007. A thermo-economical optimization of a domestic solar heating plant with seasonal storage. Applied Thermal Engineering 27, 450-456.

[14] Durao, B., Joyce, A., Mendes, J.F., 2014. Optimization of a seasonal storage solar system using genetic algorithms.Sol. Energy 101, 160- 166.

[15] Milewski, J., Wołowicz, M., Bujalski, W., 2014. Seasonal thermal energy storage-a size selection. Appl. Mech. Mater. 467, 270-276.

[16]Yumrutas, R., Unsal, M., 2000. Analysis of solar aided heat pump systems with seasonal thermal energy storage in surface tanks. Energy 25, 1231-1243.

[17] Xu J. Wang RZ, Li Y, (2014). Performance investigation of a solar heating system with underground seasonal energy storage for green house application. Power Machinery and Engineering of Ministry of Education, 67, 63-73.

[18] Saeid Jafarzadeh-Ghoushchi, Abbas Sharifi, Mohsen Ahmadi, Mohammad Reza Maghami ,Statistical Study of Seasonal Storage Solar System Usage in Iran.Journal of Solar Energy Research (JSER).

[19] Milo`sBanjac. Achieving sustainable work of the heat pump with the support of anunderground water tank and solar collectors. Energy and Buildings 98 (2015) 19-26.

[20] Benzaama MH, Menhoudj S, Kontoleon KJ, Mokhtari AM,Lekhal MC, Investigation of the thermal behavior of a combined geothermal systemfor cooling with regards to Algeria's climate, Sustainable Cities and Society (2018),https://doi.org/10.1016/j.scs.2018.08.016.

[21] A. CARRILLO ANDRES, J. M. CEJUDO,Trnsys model of a thermosiphon solar domestic water heater with a horizontal store and mantle heat exchanger.Solar Energy Vol. 72, No. 2, pp. 89-98, 2002.

[22] TRNSYS 16Volume 5 Mathematical Reference.

[23] S. Wang, Evaluating the low exergy of chilled water in a radiant cooling system,Energy and Buildings, 2008, Vol.40, pp. 1856-1865.

[24] Mohamed-Hichem Benzaamaa, Mohammed Lachi, Chadi Maalouf, AbderahmaneMejedoubMokhtari, Guillaume Polidori, Mohammed Makhlouf, Study of the effect of sun 
patch on the transient thermal behaviourofa heating floor in Algeria, Energy and Buildings 133 (2016), 257-270.

[25] Sayeh Menhoudj, Abderahmane-MejedoubMokhtari, Mohamed-Hichem Benzaama, Chadi Maalouf, Mohammed Lachi, Mohammed Makhlouf, Study of the energy performance of an earth-Air heat exchanger for refreshing buildings in Algeria. Energy and Buildings 158 (2018) 1602-1612.

[26]Olesen, Bjarne W. (September 2008). "Hydronic Floor Cooling Systems".ASHRAE Journal.

[27] [Sonntag 90] Sonntag D.: Important New Values of the Physical Constants of 1986, Vapour Pressure Formulations based on the IST-90 and Psychrometer Formula ; Z. Meteorol., 70 (5), pp. 340-344, 1990.

[28] TRNSYS 16 a TRaNsientSYstem Simulation program Volume 5, Mathematical Reference.

[29] Tomasz Cholewa, Marian Rosínski, Zenon Spik, Marzenna R. Dudzi’nska, AlicjaSiutaOlcha. On the heat transfer coefficients between heated/cooled radiant floor and room. Energy and Buildings 66 (2013) 599-606.

[30] Kedaid, F.Z., 2007. Database of the geothermal resources of Algeria.Geothermics 36, $265-275$.

[31] Lekhal, M. C., Belarbi, R., Mejedoub Mokhtari, A., Benzaama, M.-H., Bennacer, R. Thermal performance of a residential house equipped with a combined system: A direct solarfloor and an earth-air heat exchanger. Sustainable Cities and Society, 40, 534-545. 


\section{List of Figures Captions}

Figure 1: Heat flow exchanged with the buried tank.

Figure 2: Presentation of the experimental cell [24].

Figure 3: The two tanks coupled to the room A of the experimental cell.

Figure 4: Connection of the tanks by the manholes.

Figure 5: Evolution of the outside temperature and the relative humidity.

Figure 6: Evolution of the temperature of the surface and inlet of the cooling floor.

Figure 7: Comparison between the dew temperature and surface temperature of cooling floor

Figure 8: Evolution of the indoor air temperature.

Figure 9: Temperature recording device.

Figure 10: Measured water temperature at the inlet and outlet of the tank.

Figure 11: Evolution of the indoor air temperature for 15 days in July 2017 when the floor is coupled to only one tank.

Figure 12: Interface simulation under Trnsys.

Figure 13: Experimental indoor air temperature and simulation.

Figure 14: Surface temperature of the experimental cooling floor and simulation.

Figure 15: The experimental and simulation water temperature at the tank inlet.

Figure 16: Temperature of experimental and simulation indoor air.

Figure 17: Evolution of temperatures $\left(\mathrm{T}_{\mathrm{amb}}, \mathrm{T}_{\mathrm{ave}}\right.$ of water, $\left.\mathrm{I}_{\text {nterface ground tank }}\right)$ over a period of a year in free evolution.

Figure 18: Evolution of temperatures $\left(\mathrm{T}_{\mathrm{amb}}, \mathrm{T}_{\mathrm{ave}}\right.$ of water, $\mathrm{I}_{\mathrm{n} \text { terface ground tank }}$ )as a function of the burial depth and the temperature of the outside air.

Figure 19: Evolution of temperatures $\left(\mathrm{T}_{\mathrm{amb}}, \mathrm{T}_{\mathrm{ave}}\right.$ of water, $\left.\mathrm{I}_{\text {nterface ground tank }}\right)$ as a function of the burial depth $(Z=3 \mathrm{~m}, 5 \mathrm{~m}$ and $10 \mathrm{~m})$. 
Figure 20: Influence of the volume on the average temperature of the water.

Figure 21: Distribution of geothermal gradient in Algeria [30].

Figure 22.a: Influence of the climate site on the average temperature of the water (volume of $\left.2 \mathrm{~m}^{3}\right)$

Figure 22.b: Influence of the climate site on the average temperature of the water (volume of $\left.4 m^{3}\right)$

Figure 23: Evolution of the outlet water temperature (July month).

Figure 24: Evolution of temperatures $\left(\mathrm{T}^{\circ}{ }_{\text {int }}, \mathrm{T}^{\circ}\right.$ floor, $\left.\mathrm{T}^{\circ}{ }_{\text {ext }}\right)(\mathrm{July}$ month).

Figure 25: Evolution of the indoor temperature of the room (July month).

Figure 26: Evolution of the indoor air temperature of the room (July month).

\section{List of Tables Captions}

Table 1: Composition of the vertical walls [24].

Table 2: Composition of the high floor [24].

Table 3: Characteristics of the reversible floor (heating / cooling) [24].

Table 4:Physical properties of the soil [25].

Table 5: Average temperatures of ambient air for Oran, Bechar and Adrar [25].

Table 6: Gain temperature and coverage rate for different cases. 


\section{List of Tables}

Table 1 : Composition of the vertical walls [24].

\begin{tabular}{|c|c|}
\hline Material & Thickness (cm) \\
\hline Cement coating & $1 \mathrm{~cm}$ \\
\hline First brick wall & $10 \mathrm{~cm}$ \\
\hline Polystyrene insulation & $4 \mathrm{~cm}$ \\
\hline Second brick wall & $10 \mathrm{~cm}$ \\
\hline Plaster coating & $1 \mathrm{~cm}$ \\
\hline
\end{tabular}

Table 2: Composition of the high floor [24].

\begin{tabular}{|c|c|}
\hline Material & Thickness (cm) \\
\hline Sealing & $3 \mathrm{~cm}$ \\
\hline Shaped slope & $2 \mathrm{~cm}$ \\
\hline Insulation & $2 \mathrm{~cm}$ \\
\hline Floor hollow core (hollow core + & $(16+4) \mathrm{cm}$ \\
\hline compression slab) & $1,5 \mathrm{~cm}$ \\
\hline Plaster coating & \\
\hline
\end{tabular}


Table 3: Characteristics of the reversible floor (heating / cooling) [24].

\begin{tabular}{|c|c|c|c|c|}
\hline Composition & $\begin{array}{c}\text { Thickness }(\mathbf{e}) \\
(\mathbf{m})\end{array}$ & $\begin{array}{c}\text { Conductivity } \boldsymbol{\lambda} \\
(\mathbf{W} / \mathbf{m} . \mathbf{K})\end{array}$ & $\begin{array}{c}\text { Density } \mathbf{\rho} \\
\left(\mathbf{k g} / \mathbf{m}^{\mathbf{3}}\right)\end{array}$ & $\begin{array}{c}\text { Capacity Cp } \\
(\mathbf{J} / \mathbf{k g} \cdot \mathbf{K})\end{array}$ \\
\hline Gerflex coating & 0.003 & 0.31 & 1190 & 1046 \\
\hline Paving & 0.10 & 0.75 & 2450 & 920 \\
\hline Cope & 0.10 & 1.75 & 2450 & $/$ \\
\hline Insulating & 0.04 & 0.03 & 38 & 920 \\
\hline
\end{tabular}

Table 4: Physical properties of the soil [25].

\begin{tabular}{|l|c|c|c|}
\hline Nature du sol & $\begin{array}{c}\text { Thermal conductivity } \\
(\mathbf{w} / \mathbf{m} . \mathbf{K})\end{array}$ & $\begin{array}{c}\text { Thermal capacity } \\
(\mathbf{k J} / \mathbf{k g} . \mathbf{K})\end{array}$ & $\begin{array}{c}\text { Density } \\
\left(\mathbf{k g} / \mathbf{m}^{\mathbf{3}}\right)\end{array}$ \\
\hline Loamy clay soil & 1.5 & 1.3 & 1530 \\
\hline
\end{tabular}

Table 5: Average temperatures of ambient air for Oran, Bechar and Adrar [25].

\begin{tabular}{|c|c|c|c|c|c|c|c|c|c|}
\hline \multirow[t]{2}{*}{ Month } & \multicolumn{3}{|c|}{$\begin{array}{c}\text { Ambient air temperature } \\
\left({ }^{\circ} \mathrm{C}\right) \\
\text { (Oran) }\end{array}$} & \multicolumn{3}{|c|}{$\begin{array}{c}\text { Ambient air temperature } \\
\left({ }^{\circ} \mathrm{C}\right) \\
(\mathrm{Bechar})\end{array}$} & \multicolumn{3}{|c|}{$\begin{array}{c}\text { Ambient air temperature } \\
\left({ }^{\circ} \mathrm{C}\right) \\
\text { (Adrar) }\end{array}$} \\
\hline & Tmax & Tmin & $\begin{array}{l}\text { Thermal } \\
\text { Gradient }\end{array}$ & Tmax & Tmin & $\begin{array}{l}\text { Thermal } \\
\text { Gradient }\end{array}$ & Tmax & Tmin & $\begin{array}{l}\text { Thermal } \\
\text { Gradient }\end{array}$ \\
\hline January & 16,6 & 5,1 & 11,5 & 20.9 & -1 & 21,9 & 25,5 & 0,4 & 25,1 \\
\hline february & 17,7 & 6,5 & 11,2 & 24.1 & 1.1 & 23 & 30,8 & 2,4 & 28,4 \\
\hline March & 19,7 & 8,1 & 11,6 & 28.6 & 3.8 & 24,8 & 34 & 4,8 & 29,2 \\
\hline April & 21,5 & 10 & 11,5 & 31.2 & 7.8 & 23,4 & 38 & 9,1 & 28,9 \\
\hline May & 23,9 & 13,2 & 10,7 & 36.7 & 8.9 & 27,8 & 42,4 & 11,7 & 30,7 \\
\hline June & 27,7 & 16,9 & 10,8 & 39.8 & 16.2 & 23,6 & 45,3 & 19,3 & 26 \\
\hline July & 30,5 & 19,4 & 11,1 & 42.4 & 20.9 & 21,5 & 46,6 & 21,8 & 24,8 \\
\hline August & 31,6 & 20,1 & 11,5 & 41.8 & 20.7 & 21,1 & 46,3 & 22 & 24,3 \\
\hline September & 29 & 17,7 & 12,7 & 40.3 & 14.3 & 26 & 45,5 & 16,4 & 29,1 \\
\hline October & 25,2 & 14 & 11,2 & 33 & 10 & 23 & 39,8 & 11,3 & 28,5 \\
\hline November & 20,6 & 9,5 & 11,1 & 27.2 & 2.3 & 24,9 & 32 & 3,8 & 28,2 \\
\hline December & 18,2 & 7,4 & 10,8 & 21.5 & 1 & 20,5 & 25,5 & $-0,5$ & 26 \\
\hline
\end{tabular}


Table 6: Gain temperature and coverage rate for different cases.

\begin{tabular}{|c|c|c|}
\hline Cases & $\begin{array}{l}\text { Maximal gain } \\
\text { temperature }\end{array}$ & Coverage rate \\
\hline $\begin{array}{l}\text { Temperature of the water tank: } \\
\text { with control /without control }\end{array}$ & $2{ }^{\circ} \mathrm{C}$ & \\
\hline $\begin{array}{c}\text { Surface temperature: } \\
\text { with control /without control }\end{array}$ & $2.5^{\circ} \mathrm{C}$ & \\
\hline $\begin{array}{c}\text { Indoor air temperature : } \\
\text { without control /without heat source } \\
\text { with control/without heat source }\end{array}$ & $\begin{array}{l}4{ }^{\circ} \mathrm{C} \\
6{ }^{\circ} \mathrm{C}\end{array}$ & $40.13 \%$ \\
\hline $\begin{array}{l}\text { Indoor air temperature : } \\
\text { With night ventilation and pump control } \\
\text { / without heat source }\end{array}$ & $9^{\circ} \mathrm{C}$ & $65 \%$ \\
\hline
\end{tabular}




\section{Figures}

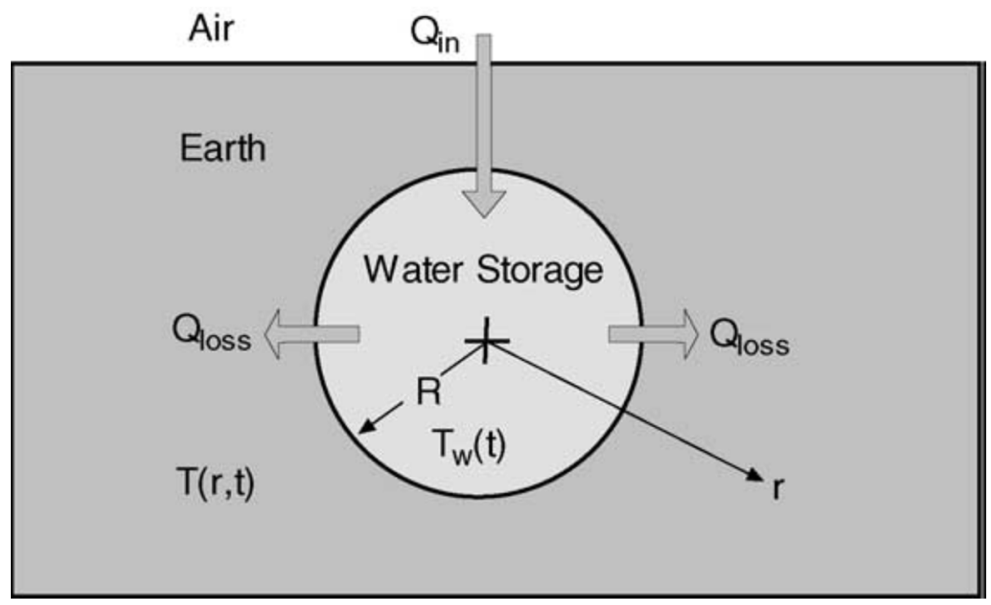

Figure 1: Heat flow exchanged with the buried tank [16].

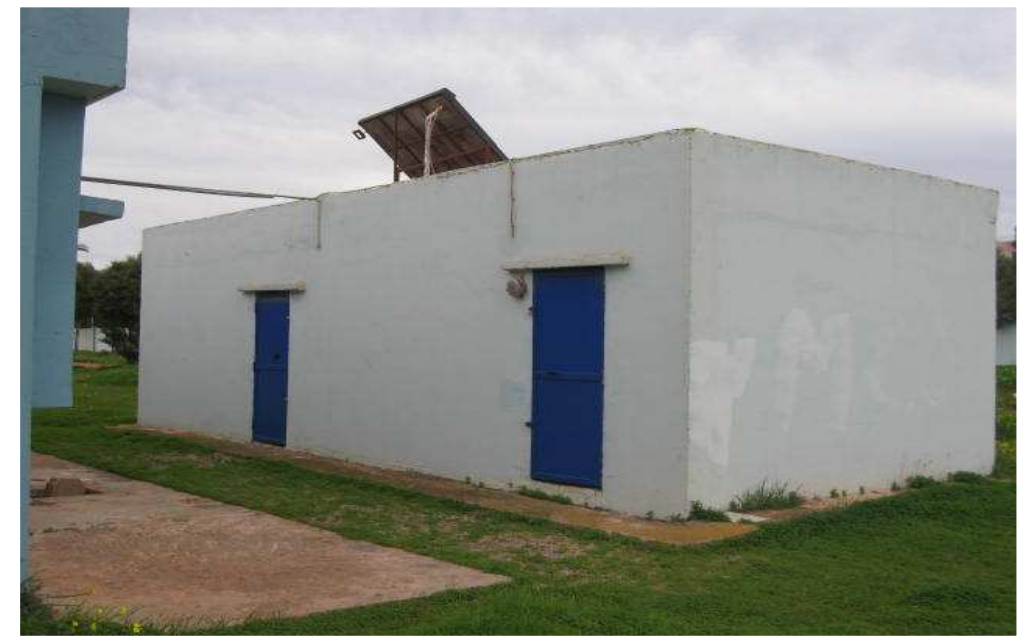

Figure 2: Presentation of the experimental cell [24]. 


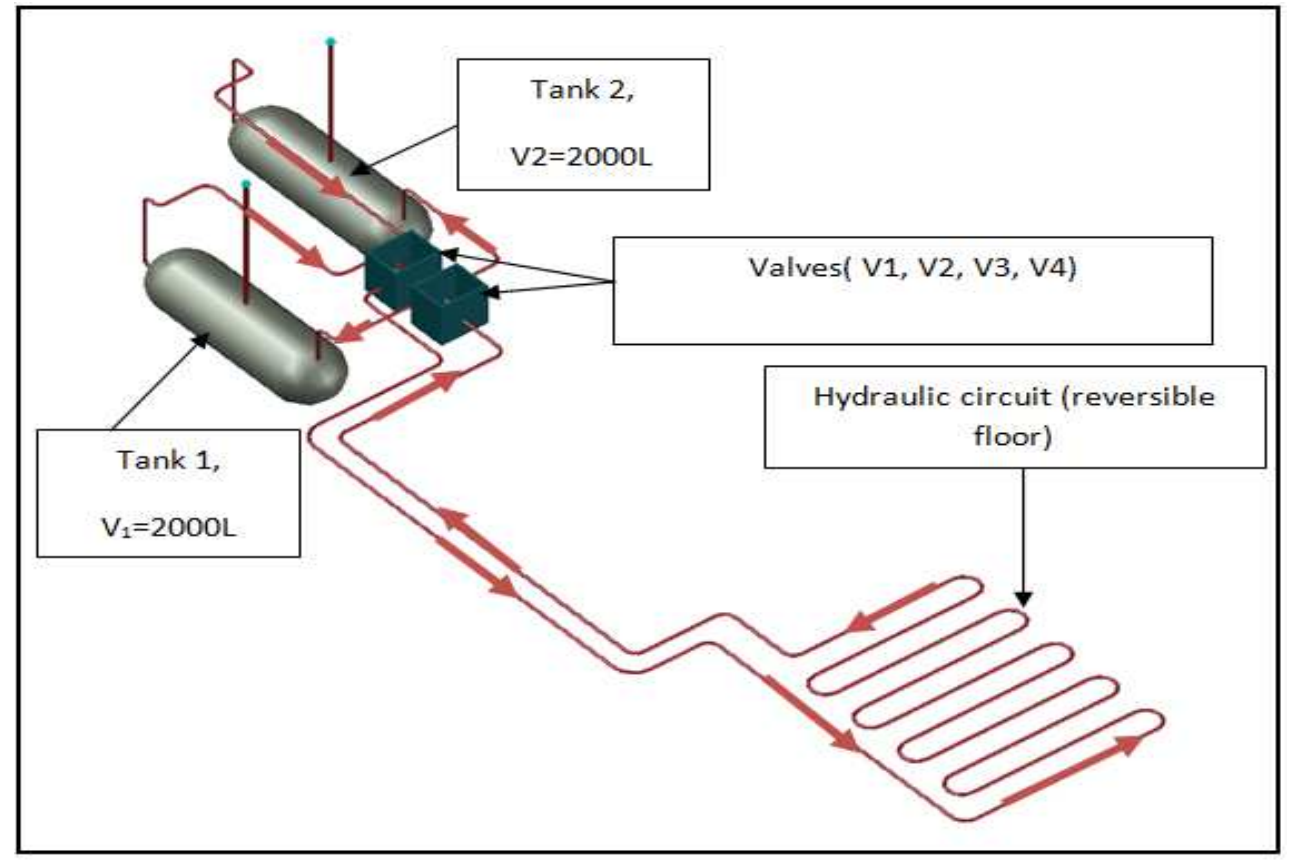

Figure 3: Diagram of the two tanks coupled to the hydraulic circuit.

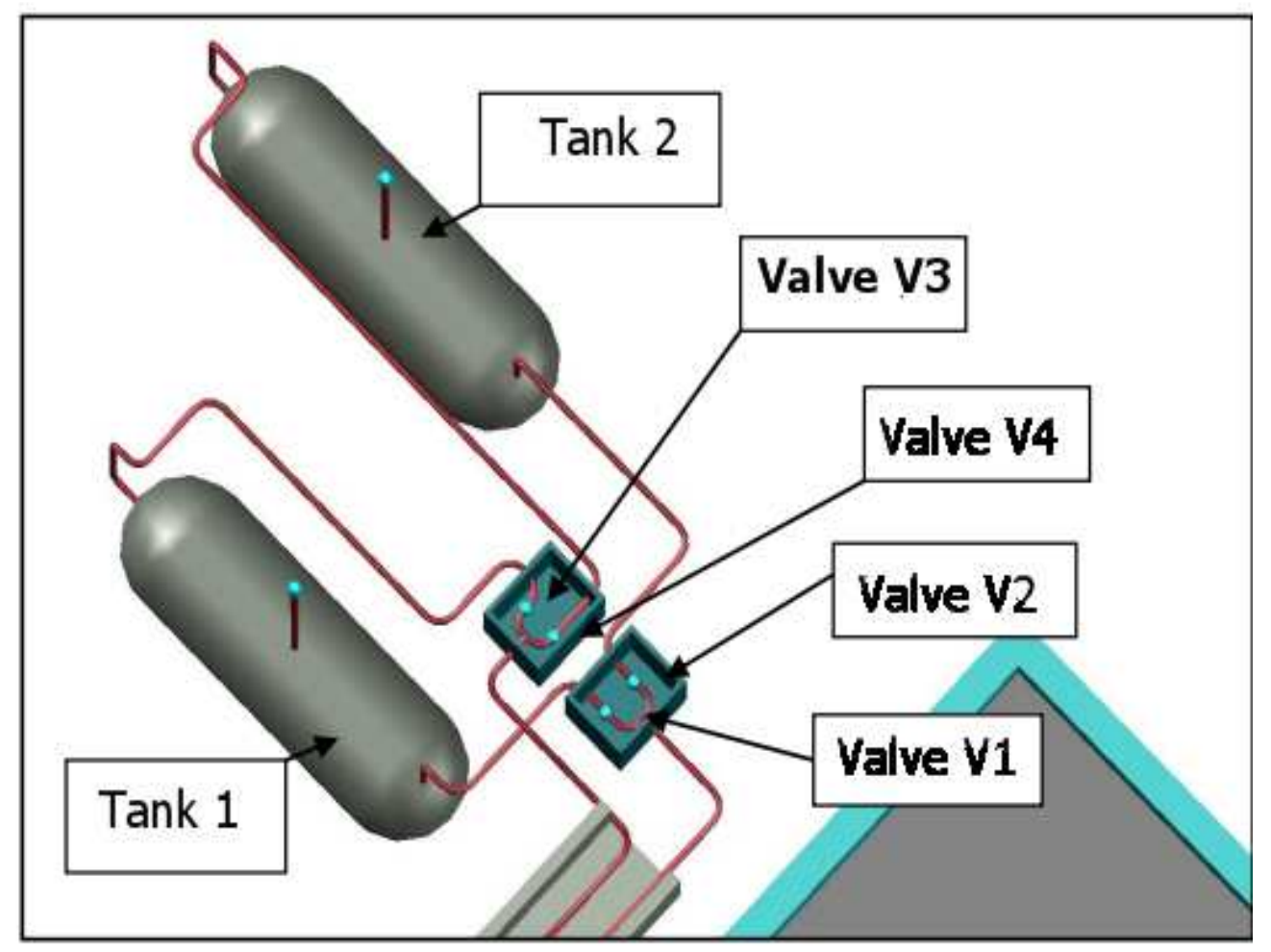

Figure 4: Connection of the tanks by the manholes. 

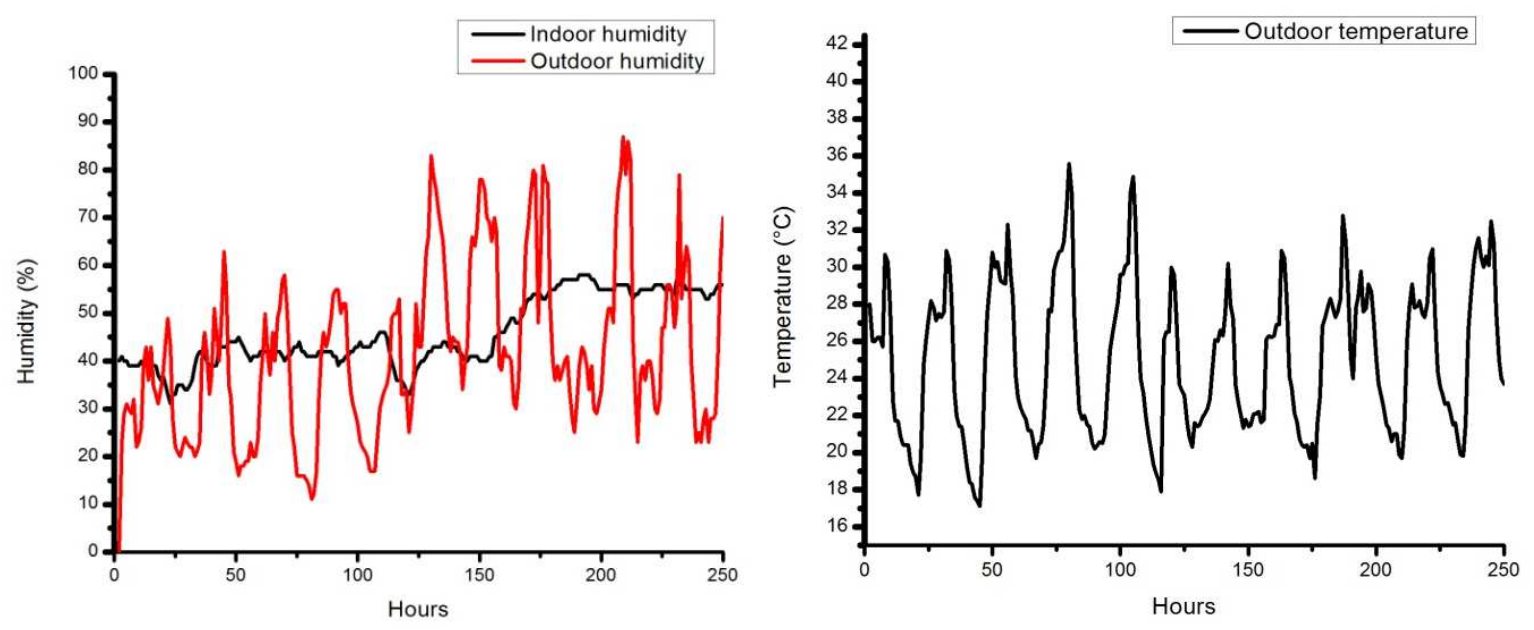

Figure 5: Evolution of the outside temperature and the relative humidity.

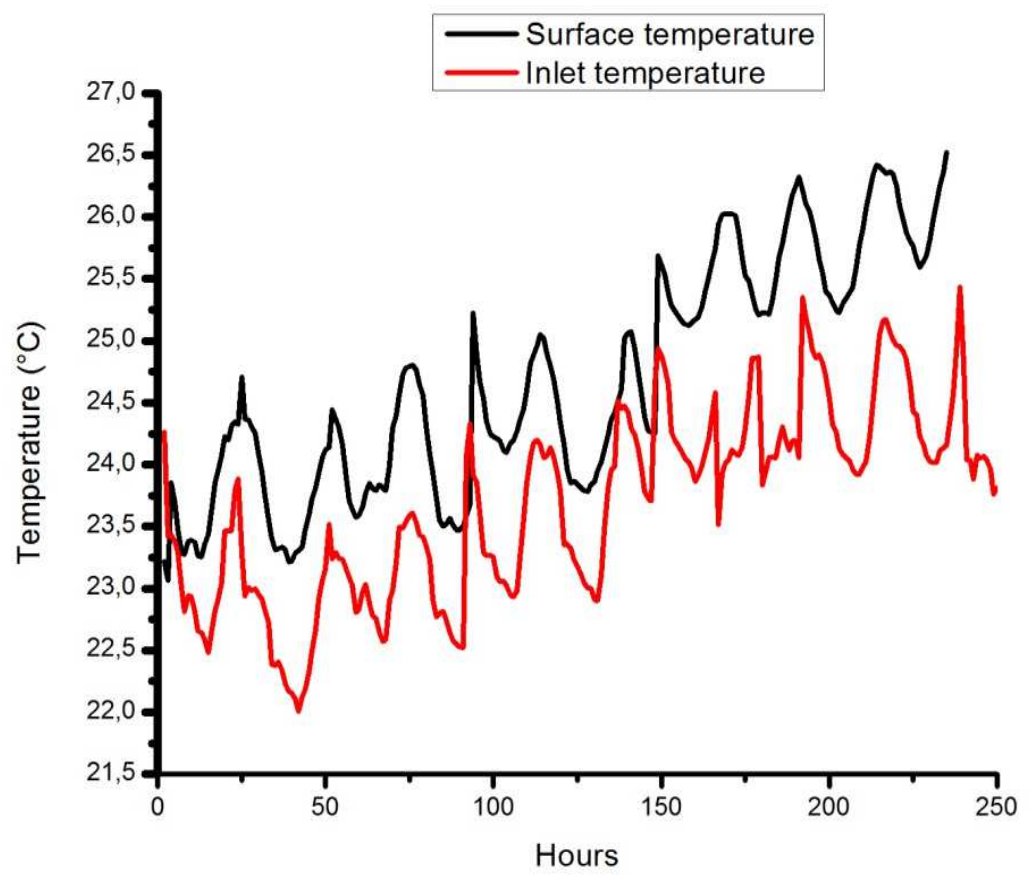

Figure 6: Evolution of the temperature of the surface and inlet of the cooling floor. 


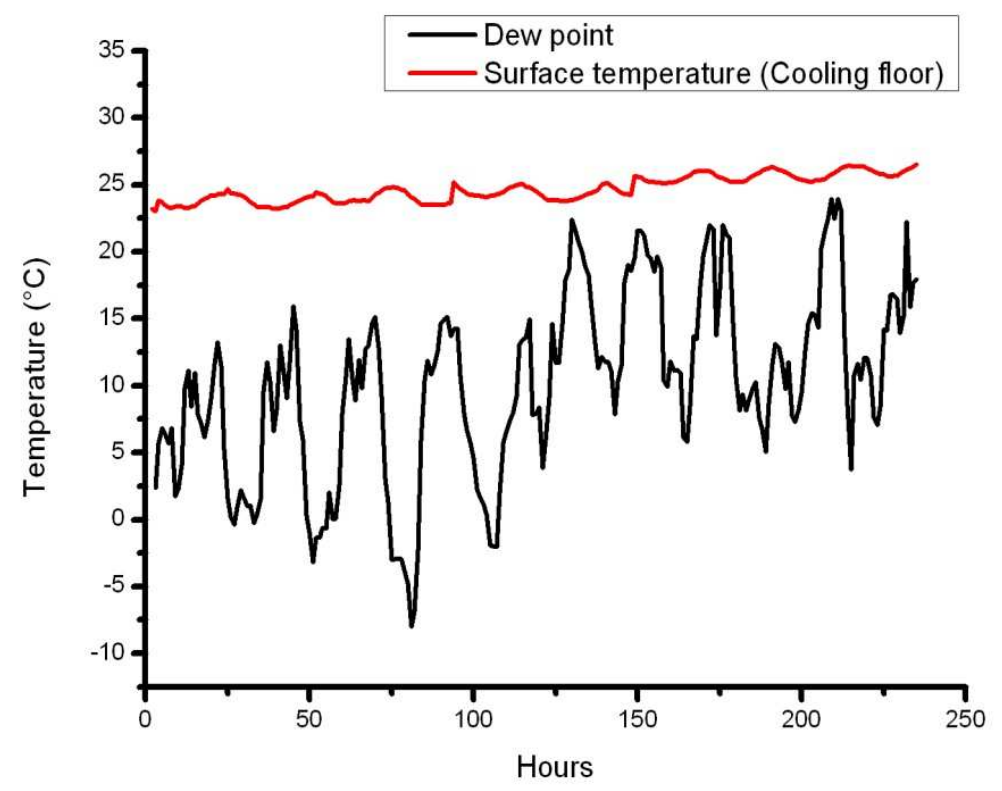

Figure 7: Comparison between the dew temperature and surface temperature of cooling floor
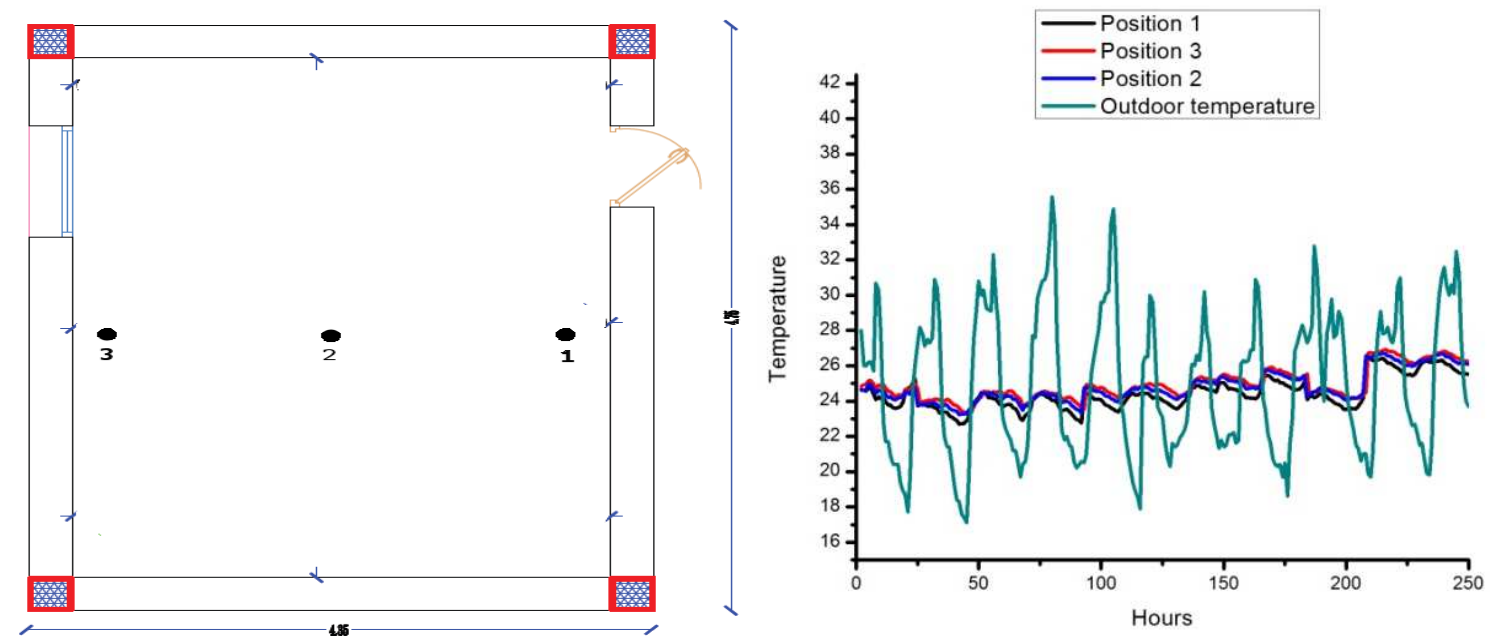

Figure 8: Evolution of the indoor air temperature. 


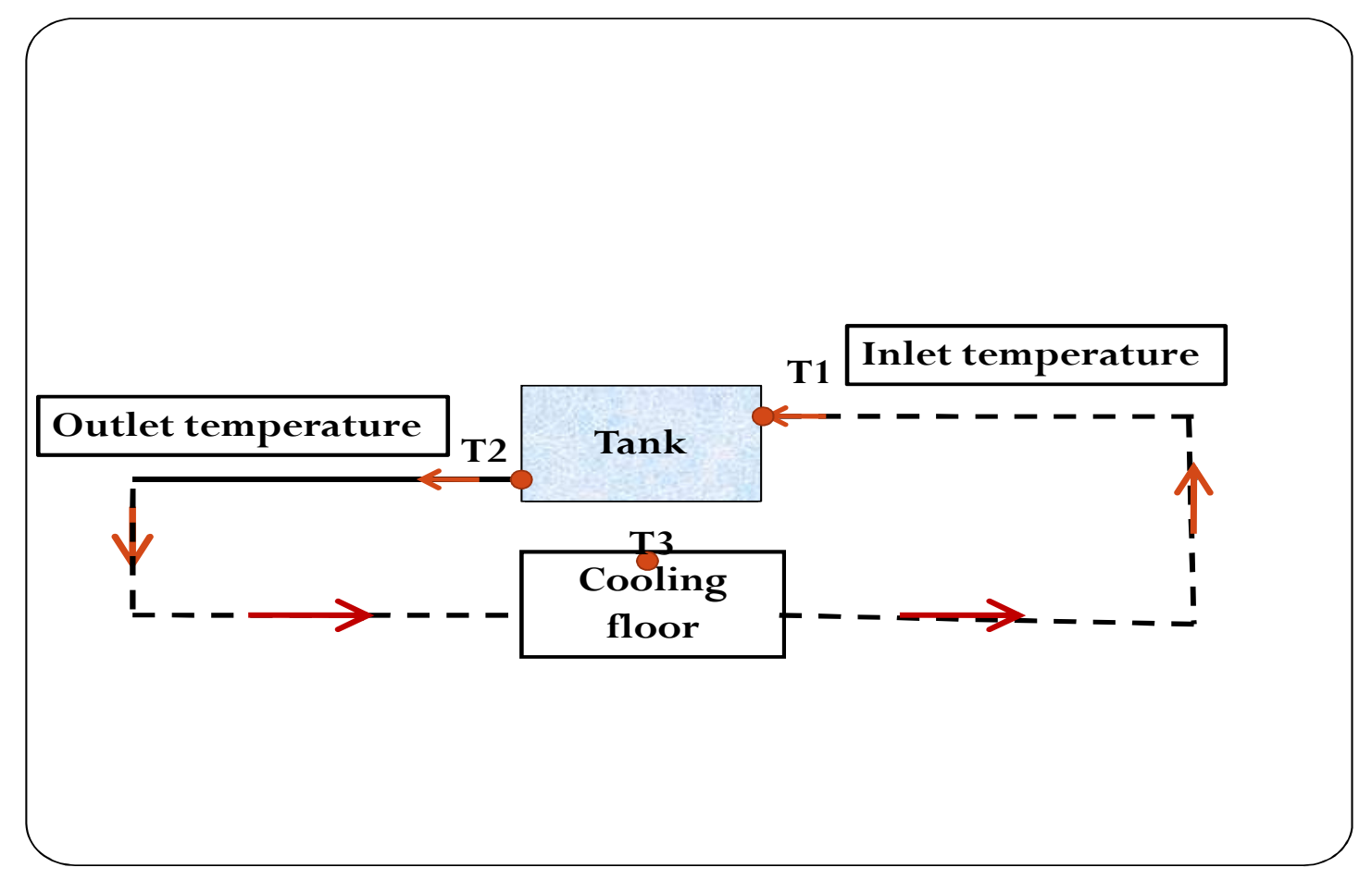

Figure 9: Temperature recording device.

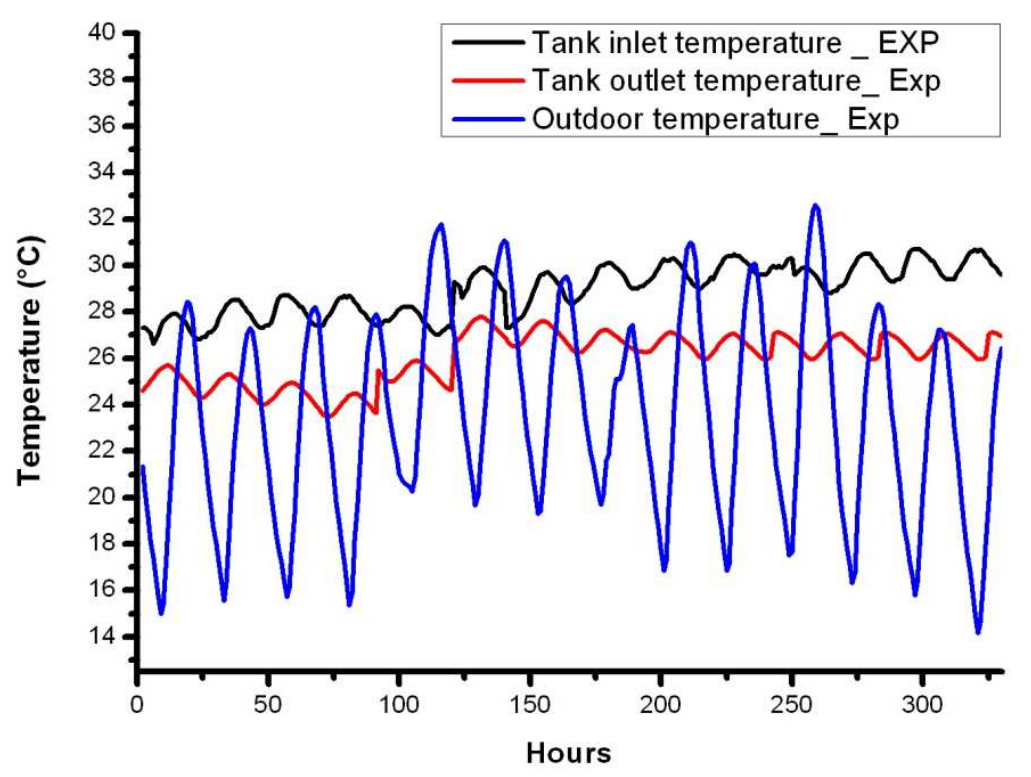

Figure 10: Measured water temperature at the inlet and outlet of the tank. 


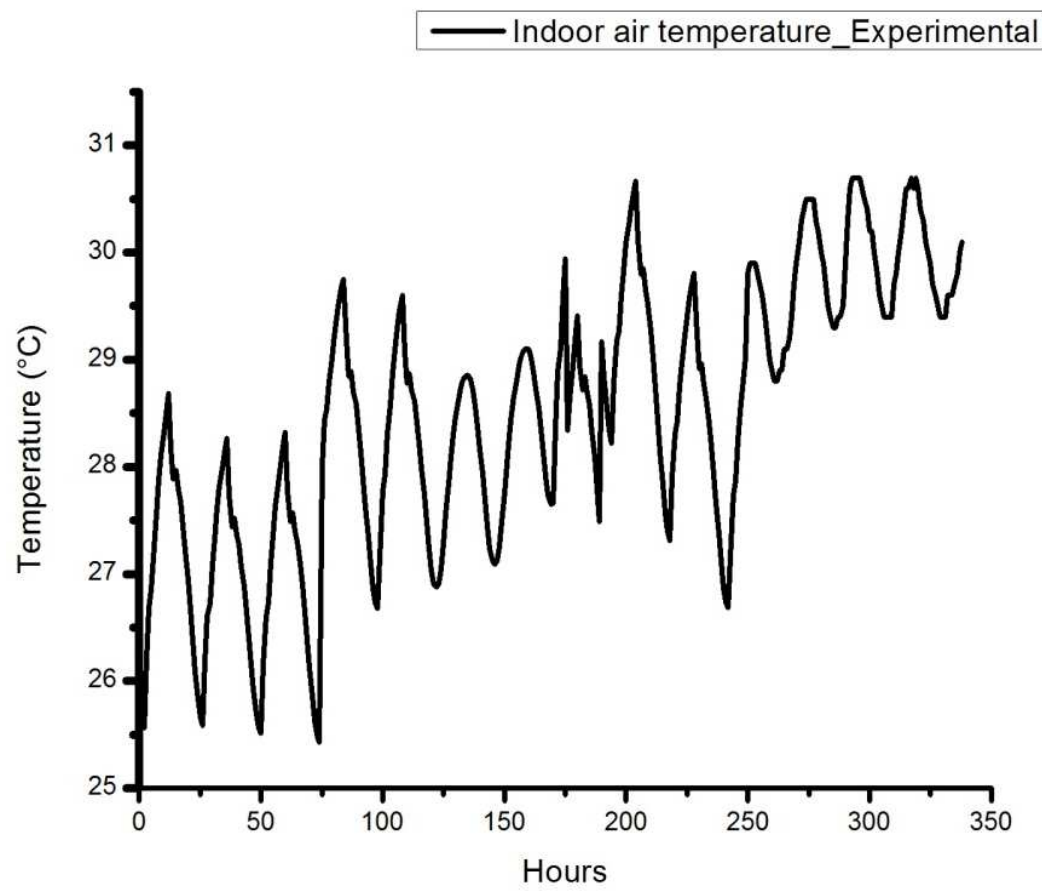

Figure 11: Evolution of the indoor air temperature for 15 days in July 2017 when the floor is coupled to only one tank. 


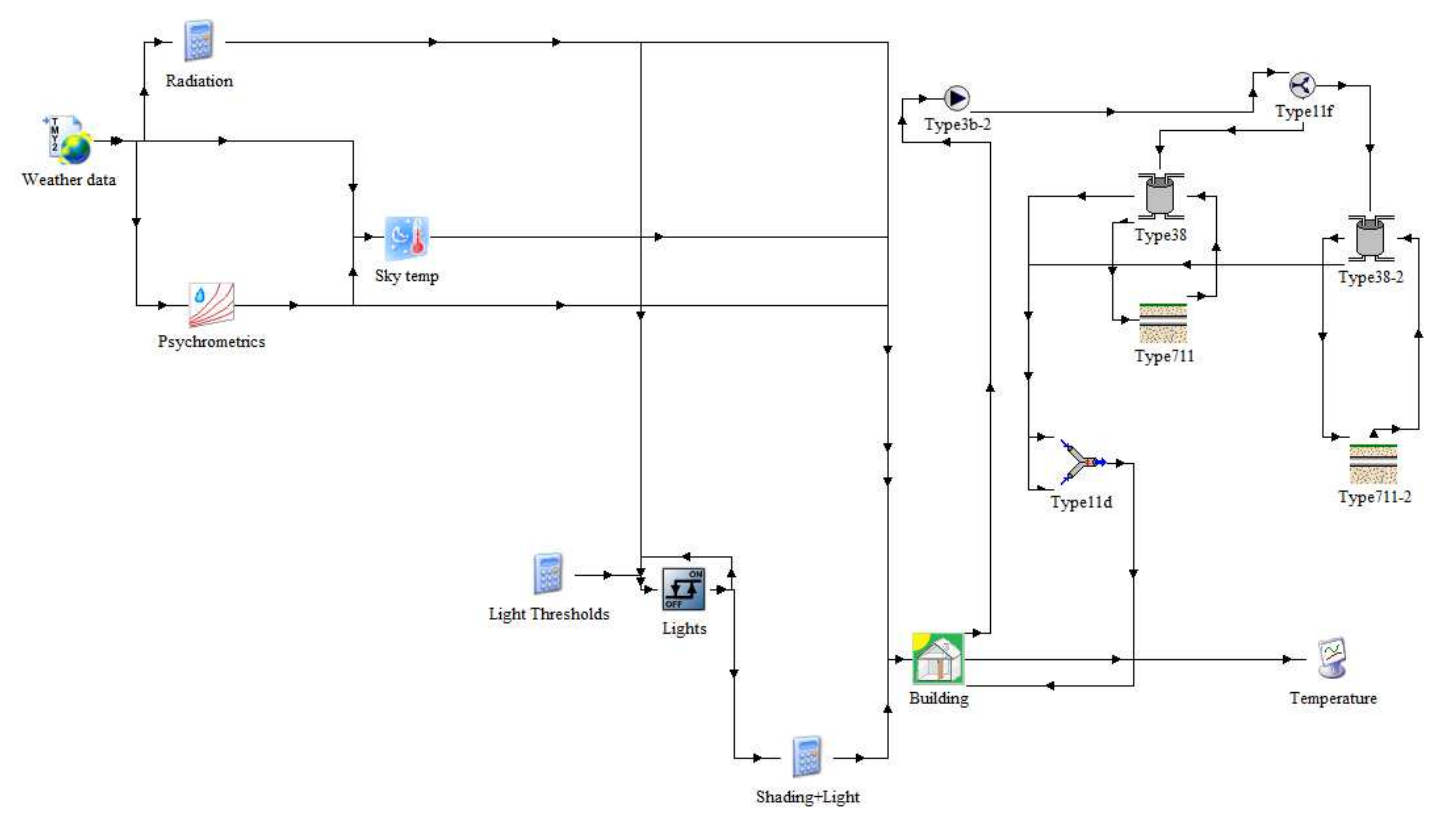

Figure 12: Interface simulation under Trnsys.

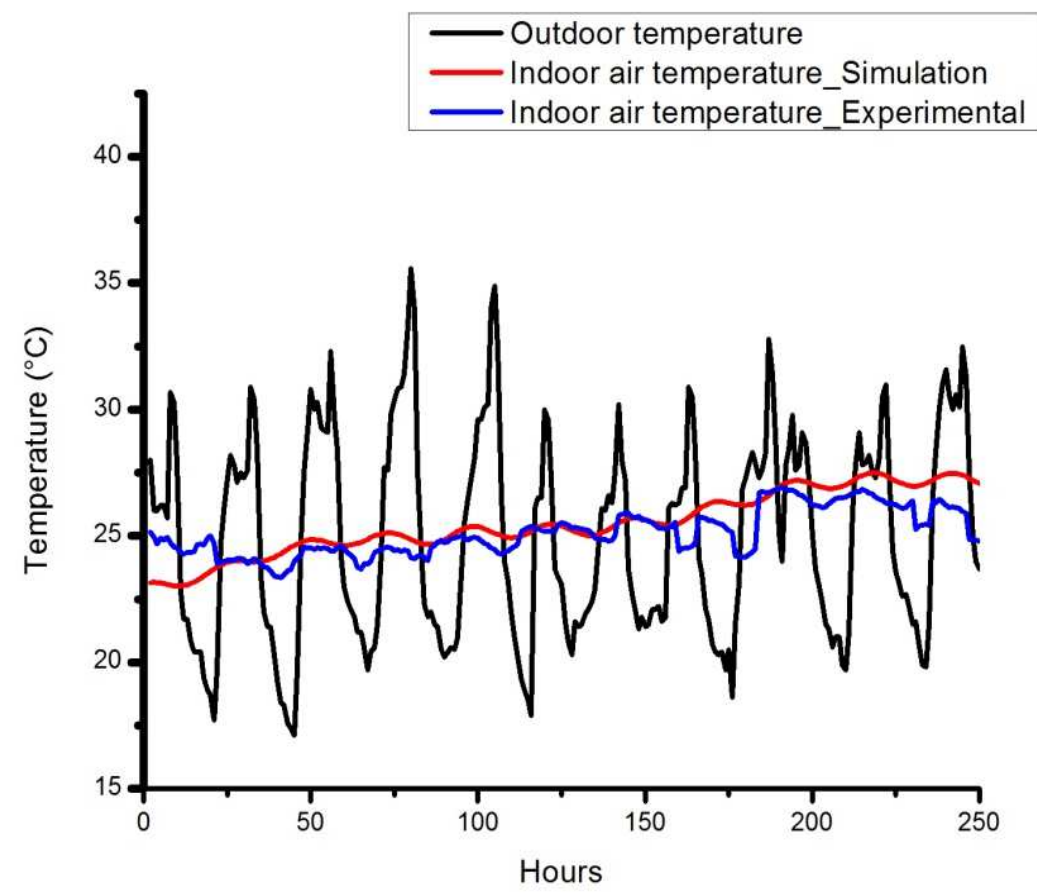

Figure 13:Experimental indoor air temperature and simulation. 


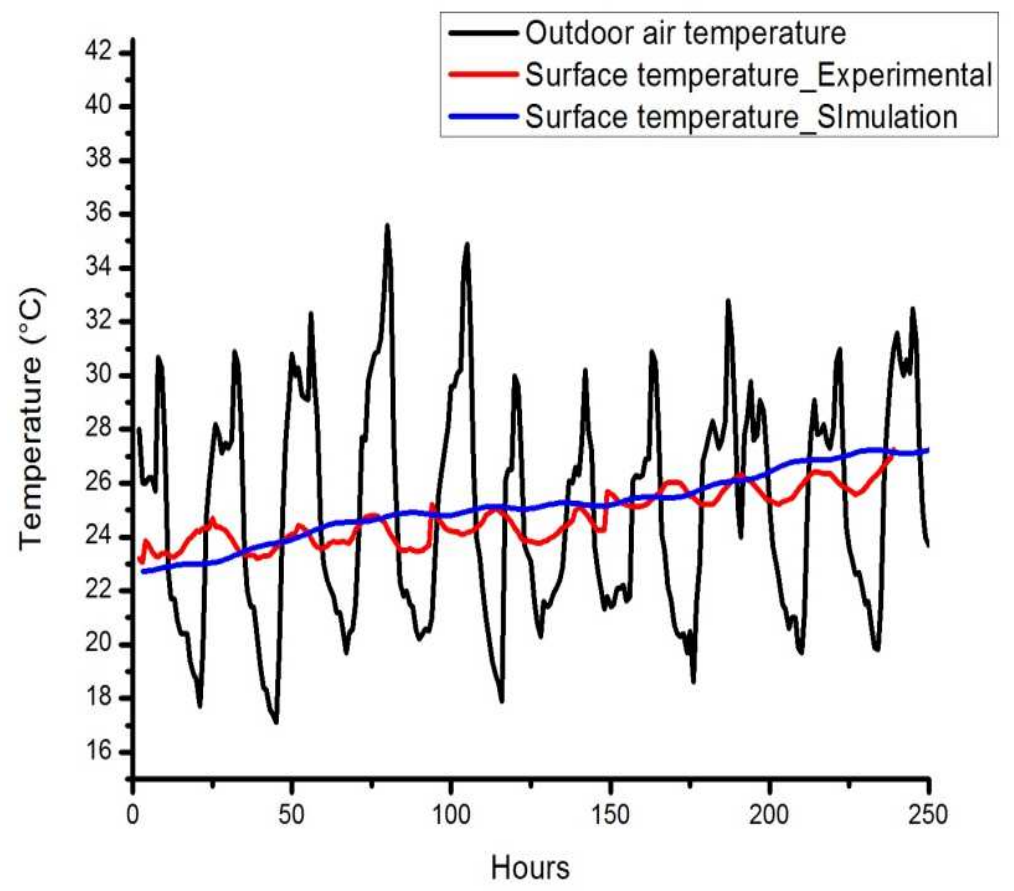

Figure 14: Surface temperature of the experimental cooling floor and simulation.

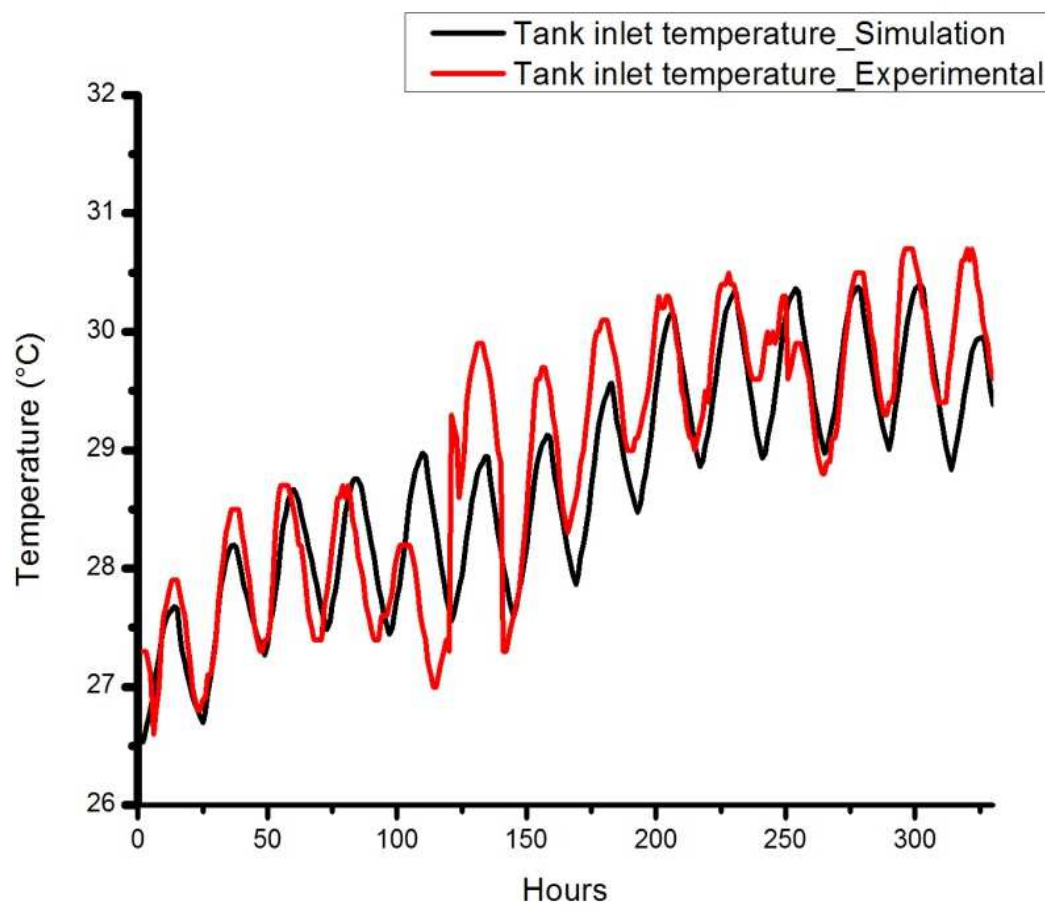

Figure 15: The experimental and simulation water temperature at the tank inlet. 


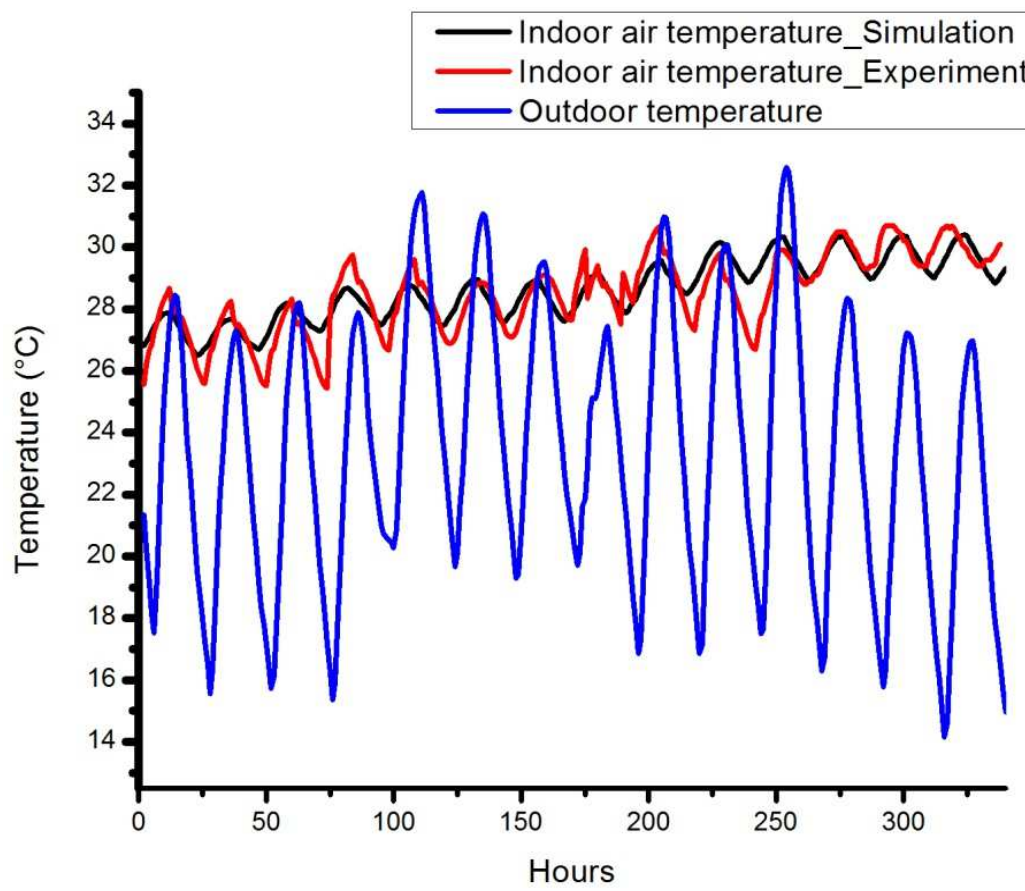

Figure 16: Temperature of experimental and simulation indoor air.

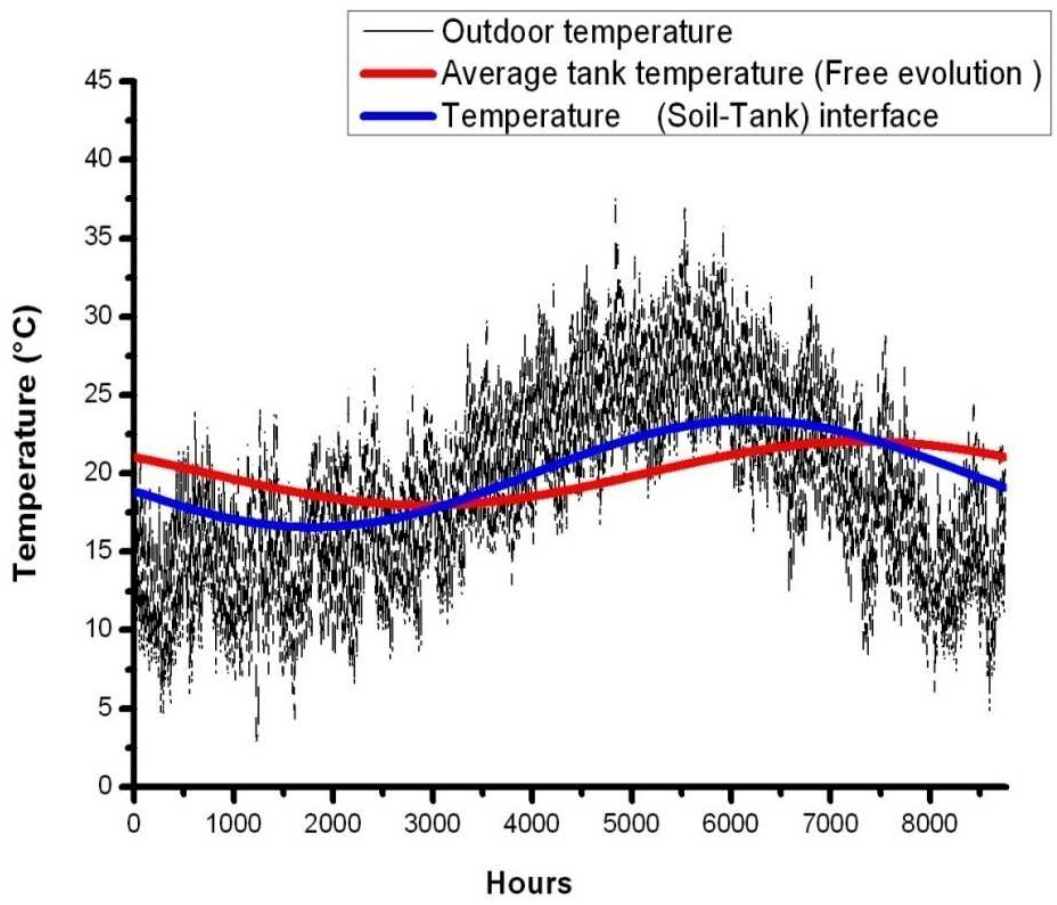

Figure 17: Evolution of temperatures $\left(\mathrm{T}_{\mathrm{amb}}, \mathrm{T}_{\mathrm{ave}}\right.$ of water, $\left.\mathrm{I}_{\text {nterface ground tank }}\right)$ over a period of a year in free evolution. 


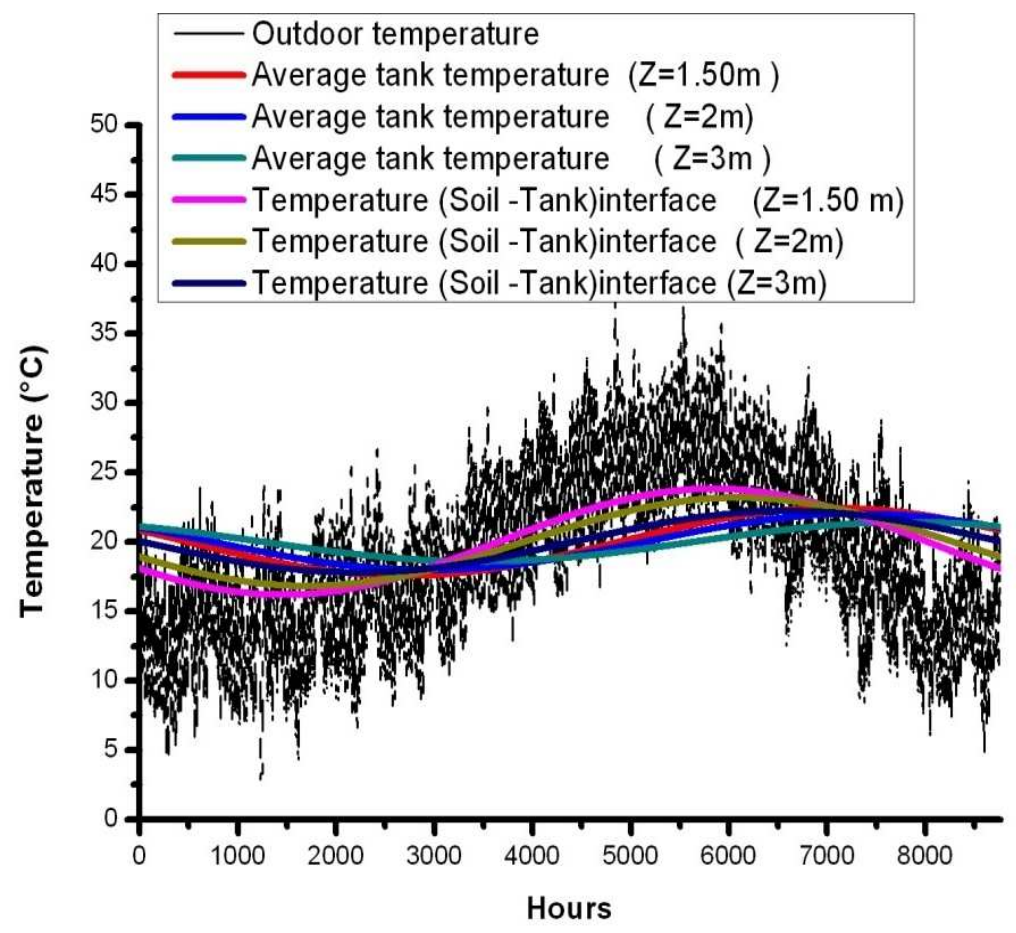

Figure 18: Evolution of temperatures ( $\left.\mathrm{T}_{\mathrm{amb}}, \mathrm{T}_{\text {ave of water }}, \mathrm{I}_{\text {nterface ground tank }}\right)$ as a function of the burial depth and the temperature of the outside air.

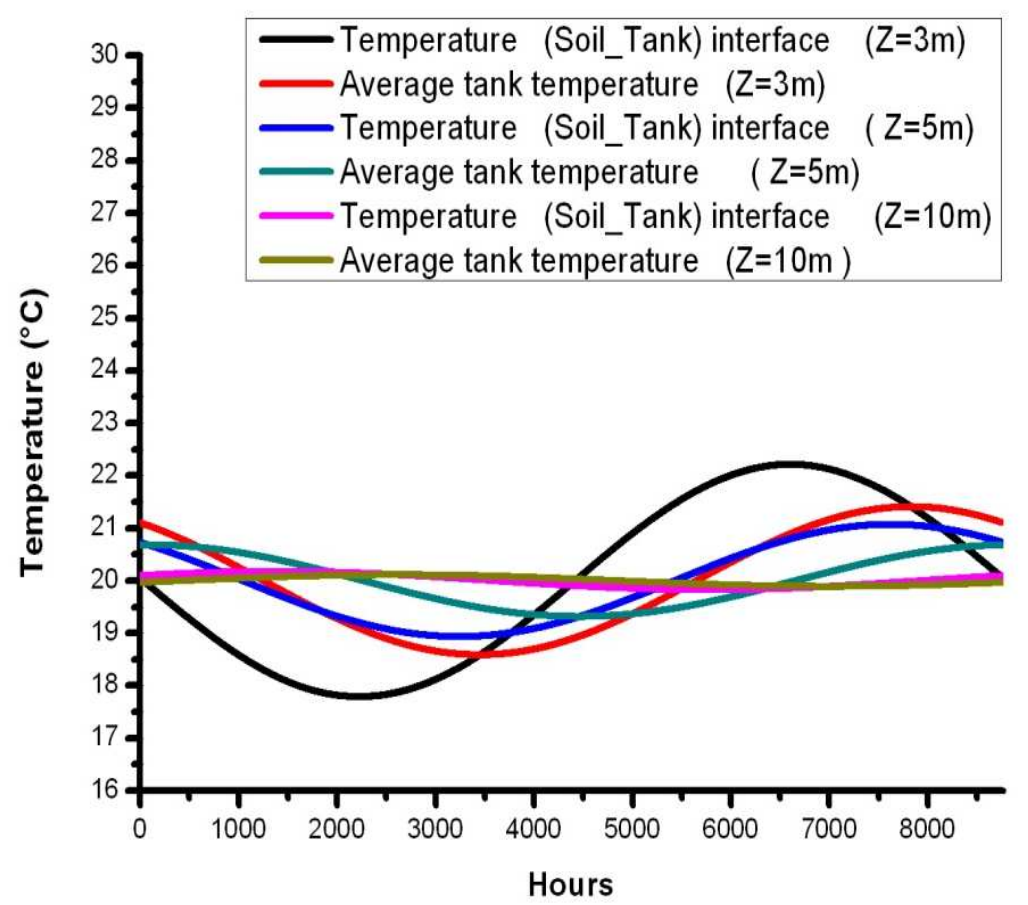

Figure 19: Evolution of temperatures $\left(\mathrm{T}_{\mathrm{amb}}, \mathrm{T}_{\mathrm{ave}}\right.$ of water, $\left.\mathrm{I}_{\text {nterface ground tank }}\right)$ as a function of the burial depth $(\mathrm{Z}=3 \mathrm{~m}, 5 \mathrm{~m}$ and $10 \mathrm{~m})$. 


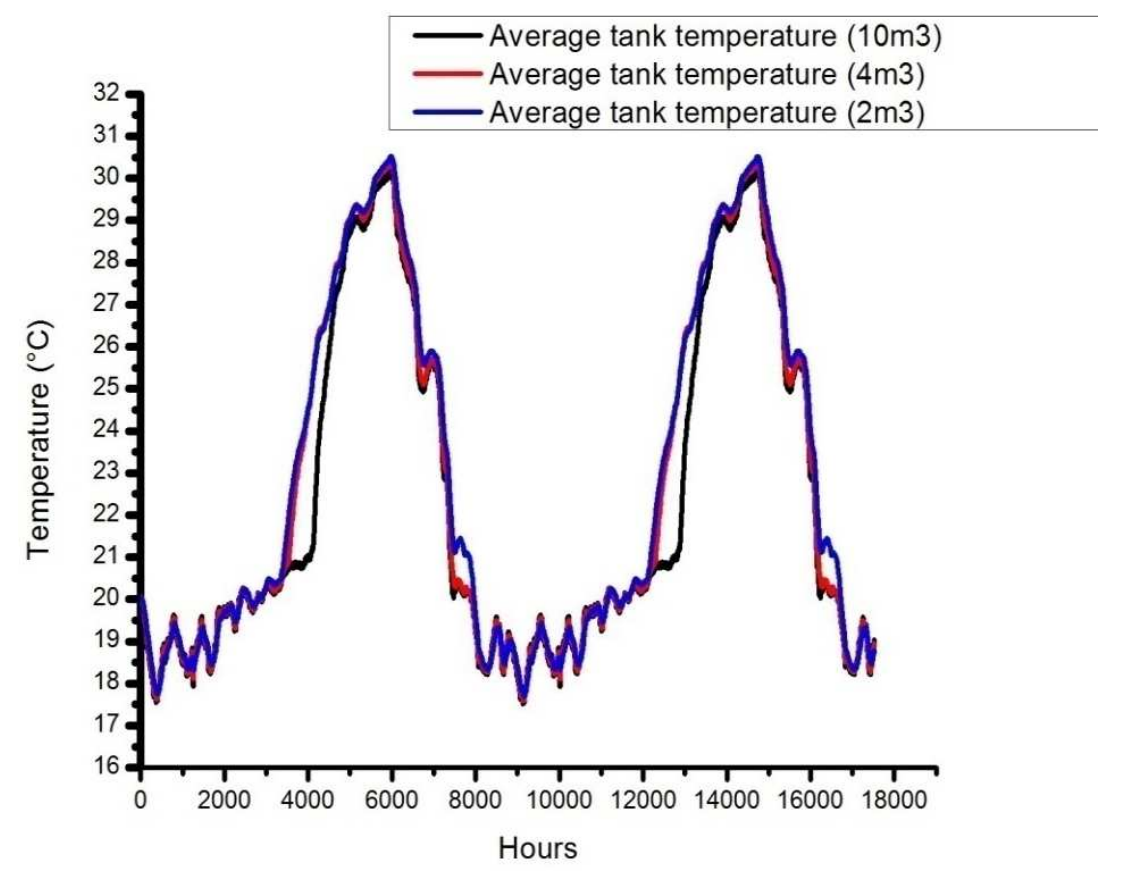

Figure 20: Influence of the volume on the average temperature of the water.

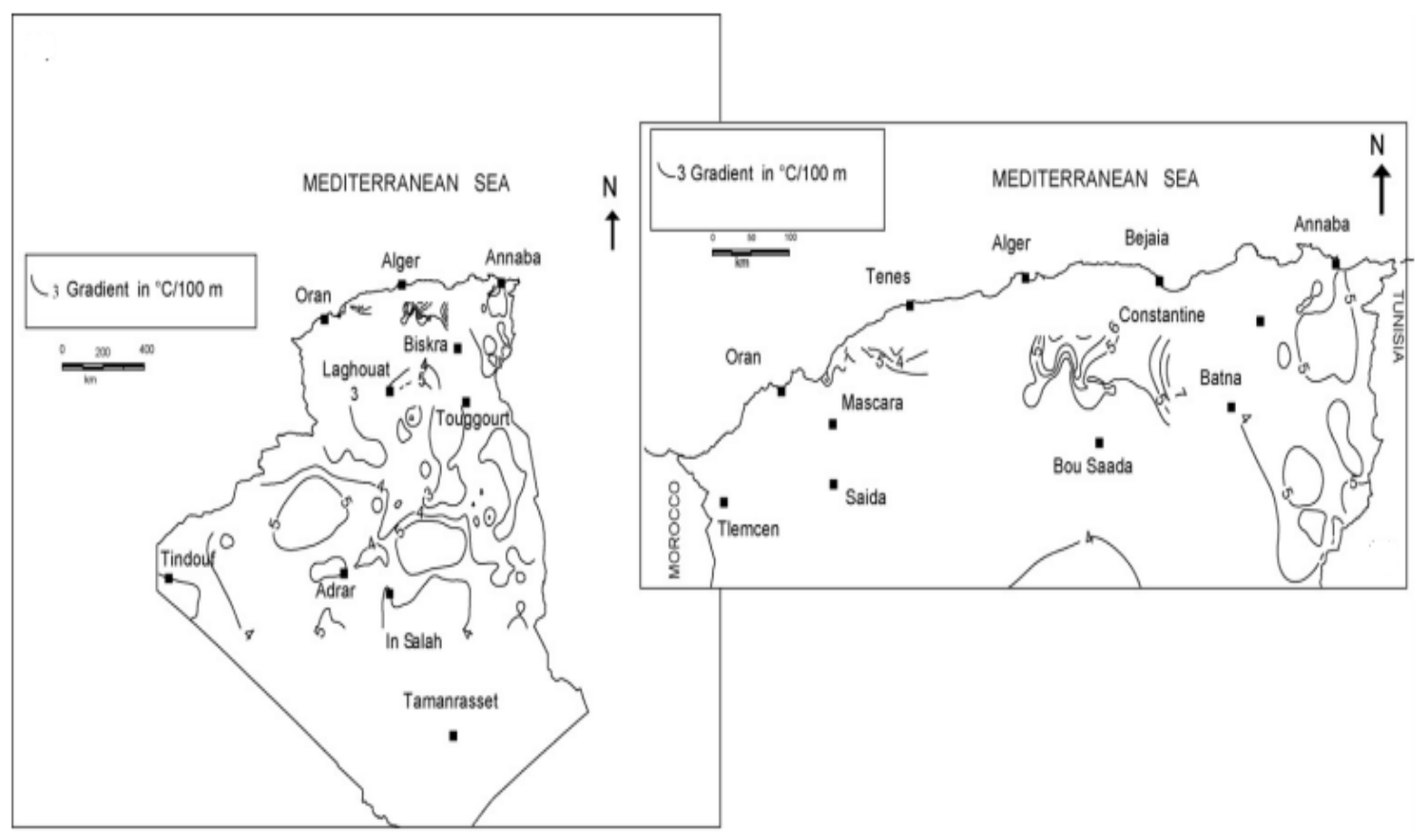

Figure 21: Distribution of geothermal gradient in Algeria [30]. 


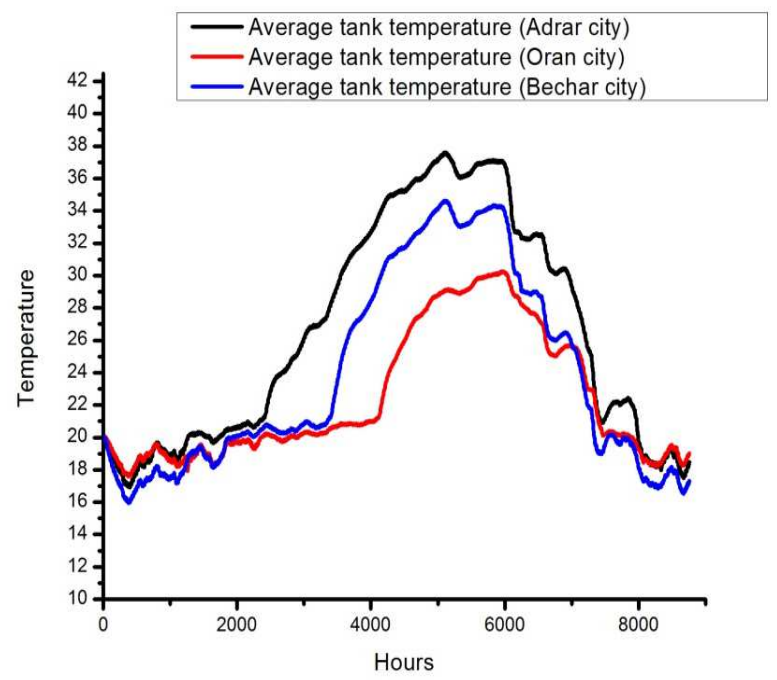

Figure 22.a: Influence of the climate site on the average temperature of the water (volume of $2 \mathrm{~m}^{3}$ )

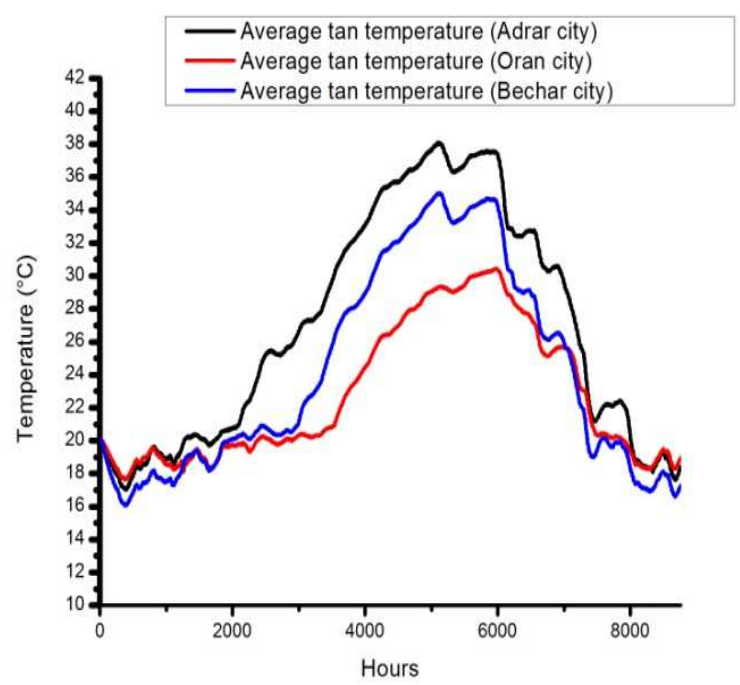

Figure 21.b: Influence of the climate site on the average temperature of the water (volume of $4 \mathrm{~m}^{3}$ )

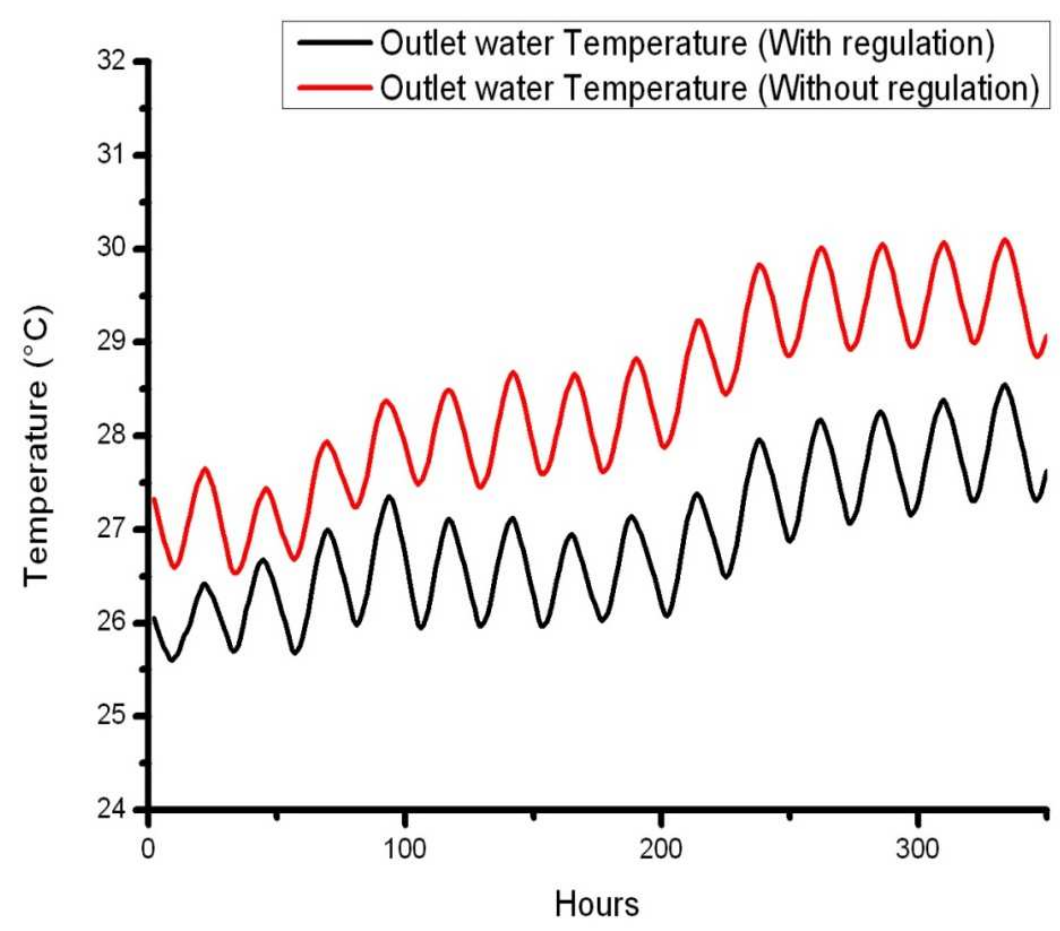

Figure 23: Evolution of the outlet water temperature (July month). 


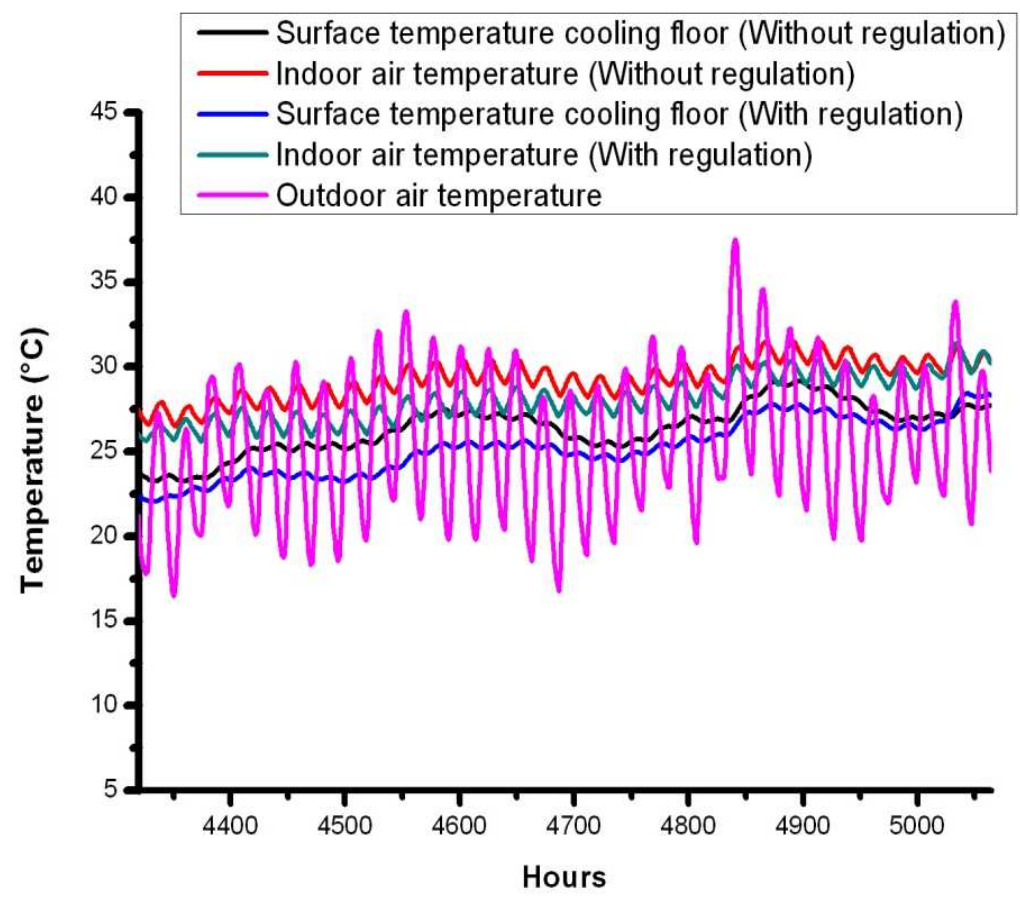

Figure 24: Evolution of temperatures $\left(\mathrm{T}^{\circ}{ }_{\text {int }}, \mathrm{T}^{\circ}\right.$ floor, $\left.\mathrm{T}^{\circ}{ }_{\text {ext }}\right)($ July month).

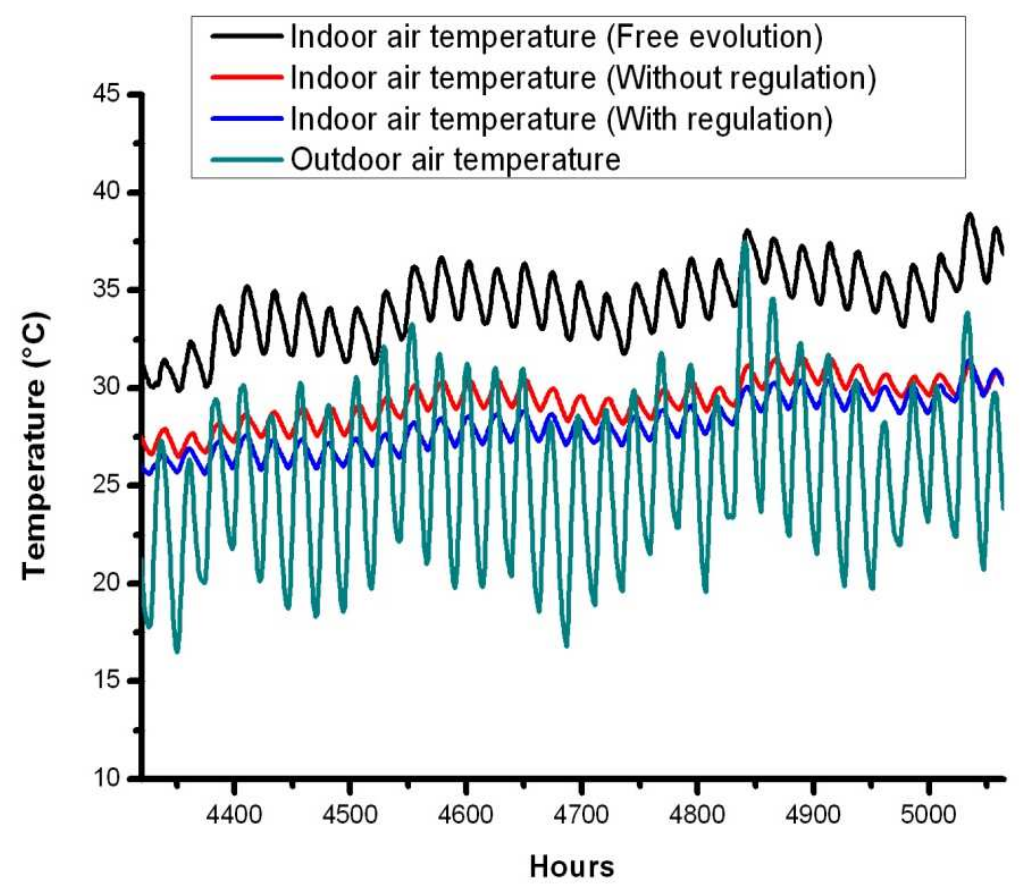

Figure 25: Evolution of the indoor temperature of the room (July month). 


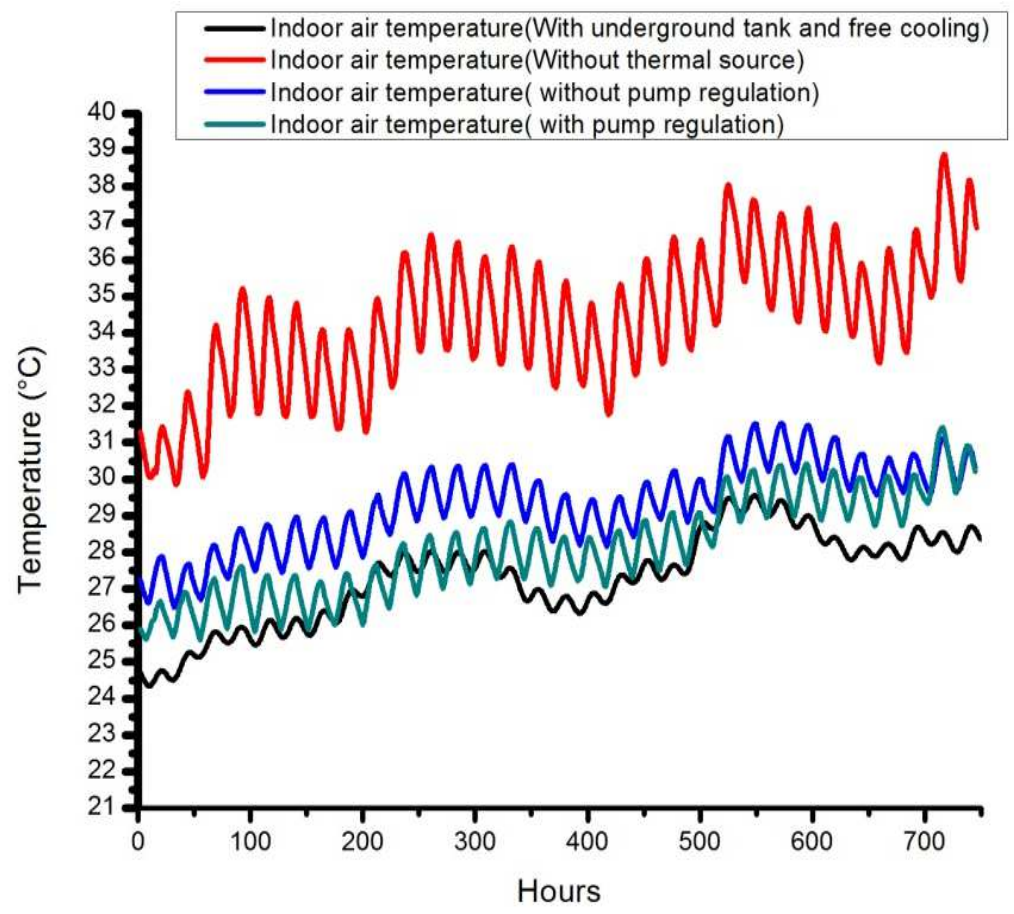

Figure 26: Evolution of the indoor air temperature of the room (July month).

\section{Highlights for review}

- An experimental study on the energy performance of a water/soil exchanger coupled to a cooling floor for cooling air of a room was carried out.

- The experimental results obtained were subjected to validation to those resulting fromthe simulation (under the code Trnsys).

- We have shown the effect of regulation and night ventilation on the energy performance of the geothermal system studied.

- The effect of the climate site, depth and volume on the water temperature of the buried tank was studied.

- In order to optimize cooling energy performance of the exchanger water/soil, parametric study was done. 